\title{
Energy partitioning and surface resistance of a poplar plantation in northern China
}

\author{
M. Kang ${ }^{1}$, Z. Zhang ${ }^{1}$, A. Noormets ${ }^{2}$, X. Fang ${ }^{1}$, T. Zha ${ }^{1}$, J. Zhou ${ }^{3}$, G. Sun ${ }^{4}$, S. G. McNulty ${ }^{4}$, and J. Chen \\ ${ }^{1}$ Key Laboratory of Soil and Water Conservation and Desertification Combating, Ministry of Education, College of \\ Soil and Water Conservation, Beijing Forestry University, Beijing 100083, PR China \\ ${ }^{2}$ Department of Forestry and Environmental Resources, North Carolina State University, Raleigh, NC, USA \\ ${ }^{3}$ Beijing Municipal Station of Agro-environmental Monitoring, Beijing 100029, PR China \\ ${ }^{4}$ Eastern Forest Environmental Threat Assessment Center, Southern Research Station, USDA Forest Service, \\ Raleigh, NC, USA \\ ${ }^{5}$ Landscape Ecology \& Ecosystem Science (LEES) Lab, Center for Global Change and Earth Observations (CGCEO), \\ and Department of Geography, Michigan State University, East Lansing, MI 48823, USA
}

Correspondence to: Z. Zhang (zhqzhang@bjfu.edu.cn)

Received: 30 October 2014 - Published in Biogeosciences Discuss.: 07 January 2015

Revised: 23 June 2015 - Accepted: 29 June 2015 - Published: 21 July 2015

\begin{abstract}
Poplar (Populus sp.) plantations have been, on the one hand, broadly used in northern China for urban greening, combating desertification, as well as for paper and wood production. On the other hand, such plantations have been questioned occasionally for their possible negative impacts on water availability due to the higher water-use nature of poplar trees compared with other tree species in water-limited dryland regions. To further understand the acclimation of poplar species to semiarid environments and to evaluate the potential impacts of these plantations on the broader context of the region's water supply, we examine the variability of bulk resistance parameters and energy partitioning in a poplar (Populus euramericana cv. "74/76") plantation located in northern China over a 4-year period, encompassing both dry and wet conditions. The partitioning of available energy to latent heat flux (LE) decreased from 0.62 to 0.53 under mediated meteorological drought by irrigation applications. A concomitant increase in sensible heat flux $(H)$ resulted in the increase of a Bowen ratio from 0.83 to 1.57. Partial correlation analysis indicated that surface resistance $\left(R_{\mathrm{S}}\right)$ normalized by leaf area index (LAI; $R_{\mathrm{S}}: \mathrm{LAI}$ ) increased by $50 \%$ under drought conditions and was the dominant factor controlling the Bowen ratio. Furthermore, $R_{\mathrm{S}}$ was the main factor controlling LE during the growing season, even in wet years, as indicated by the decoupling coefficient $(\Omega=0.45$ and 0.39 in wet and dry years, respectively). $R_{\mathrm{S}}$ was also a
\end{abstract}

major regulator of the $\mathrm{LE} / \mathrm{LE}_{\mathrm{eq}}$ ratio, which decreased from 0.81 in wet years to 0.68 in dry years. All physiological and bioclimatological metrics indicated that the water demands of the poplar plantation were greater than the amount available through precipitation, highlighting the poor match of a water-intensive species like poplar for this water-limited region.

\section{Introduction}

Poplar (Populus sp.) plantations are the most dominant broadleaf forest ecosystems throughout northern and central China, due to their rapid growth rates, high productivity and wide adaptability (Gielen and Ceulemans, 2001; Wilske et al., 2009; Zhang et al., 2011). Since the late-1970s, with the implementation of the "Three-North Shelterbelt Program" (1978), the "Combating Desertification Project" (1991), and the "Grain for Green Program (1999; Wilske et al., 2009), poplar plantations have been playing a vital role in timber production, bioenergy, urban greening, desertification control, and carbon sequestration (Martín-García et al., 2011; Zhou et al., 2013). By 2007, China had the largest poplar plantation area in the world (over 7.0 million ha, Fang, 2008). However, indiscriminate use of poplar species beyond their native range and habitats may result in unanticipated con- 
sequences. For example, the use of poplars in water-limited regions may increase the risk of environmental degradation, soil moisture deficit, hydrologic and vegetation changes (Gao et al., 2014).

Poplars require large quantities of water throughout the growing season, and may experience water limitation even on the mesic sites (Kim et al., 2008; Stanturf and Oosten, 2014). For example, poplar plantations could cause the transformation of wetlands into drylands due to the water-pumping effect on groundwater ( $\mathrm{Li}$ et al., 2014; Migliavacca et al., 2009). Thus, poplar plantations have higher productivity, but also higher water use (Zhou et al., 2013) than other tree species.

The intensive land use practices in northern China over the past 50 years, supported by irrigation, are thought to have triggered the decline in its water table, land degradation, and increases in surface air temperature and severe droughts (Ding et al., 2007; Qiu et al., 2012; Wang et al., 2008). Therefore, understanding the contribution of current land cover, including the effect of the poplar plantations on regional water resources is essential for long-term sustainability of ecosystem services and human wellbeing in this region. To date, most researchers have concentrated primarily on the water balance of forest ecosystems, with less emphasis on the relationship of forest ecosystems to their environmental setting. Much can be learned from exploring the partitioning of available energy and ecosystem responses to meteorological forcing such as droughts. Not only are these of central importance for understanding the water and carbon balance (Guo et al., 2010; Jamiyansharav et al., 2011; Sun et al., 2010; Takagi et al., 2009; Wu et al., 2007), but they also help elucidate the degree to which forest water use is in balance with supply from precipitation, and hence the degree to which plantations located in water-limited regions are sustainable in the longterm.

To investigate the variations of energy partitioning and associated evapotranspiration of poplar plantation under different climate conditions and to highlight the management strategies for such plantation forests in water- limited regions, we evaluated energy partitioning at different water availabilities in a 10-year-old poplar (Populus euramericana cv. "74/76") plantation on sandy soil in northern China. We hypothesized that drought would trigger significant increases in the surface resistance and affect energy partitioning via increasing the Bowen ratio. Specifically, the objectives of this study were to: (1) quantify the seasonal and inter-annual variability of energy partitioning and bulk resistance parameters; (2) partition the control of energy partitioning to biological and climatological components; and (3) evaluate the longterm potential impact of poplar plantations on the availability of water for adjacent ecosystems and livelihoods in waterlimited regions.

\section{Materials and methods}

\subsection{Study site}

The study was carried out in a managed poplar (Populus euramericana cv. "74/76") plantation at the Daxing Forest Farm, which is located in the southern suburbs of Beijing, China $\left(116^{\circ} 15^{\prime} 07^{\prime \prime} \mathrm{E}, 39^{\circ} 31^{\prime} 50^{\prime \prime} \mathrm{N}, 30 \mathrm{~m}\right.$ a.s.1.). The trees were planted in 1998 with $3 \mathrm{~m} \times 2 \mathrm{~m}$ spacing; dead or lowvigor trees were replaced with new saplings in 2001 and 2003. The stand characteristics over the 4 years of study are provided in Table 1. At the end of 2009, the average height of the trees was $16.2 \pm 1.6 \mathrm{~m}$ (mean $\pm \mathrm{SD}$ ), and the diameter at breast height $(\mathrm{DBH})$ was $14.1 \pm 1.6 \mathrm{~cm}$. The average leaf area index (LAI) of the stand increased over time. During the growing season, understory shrubs were kept at low density by manual removal. Perennial herbs included Chenopodium glaucum Linn., Medicago sativa L., Melilotus officinalis (L.) Lam., Salsola collina Pall., and Tribulus terrestris L.

The local climate is classified as a sub-humid warm temperate zone, with a mean (1990-2009) annual temperature of $11.6^{\circ} \mathrm{C}$; maximum and minimum temperatures are 40.6 and $-27.4^{\circ} \mathrm{C}$, respectively. The annual precipitation ranges from 262 to $1058 \mathrm{~mm}$ (1952-2000), with an average of $556 \mathrm{~mm}$, of which $60-70 \%$ falls from July to September (Daxing Weather Station, $116^{\circ} 19^{\prime} 56$ E, 39 $43^{\prime} 24 \mathrm{~N}$ ). The annual frost-free period lasts 209 days, and the total hours of sunshine reaches $2772 \mathrm{~h}$ per year with $15.5 \mathrm{MJ} \mathrm{m}^{-2} \mathrm{~d}^{-1}$ of incoming solar radiation. The average wind speed is $2.6 \mathrm{~m} \mathrm{~s}^{-1}$ and it mostly comes from the southeast (during the growing season) and the northwest (outside of the growing season).

The study area is on the alluvial plain of the Yongding River, and is flat with an average slope of $<5^{\circ}$. The top $2 \mathrm{~m}$ of the soil is mostly composed of well-drained fluvial sand with a bulk density of $1.43-1.47 \mathrm{~g} \mathrm{~cm}^{-3}$, and a $\mathrm{pH}$ of $8.25-$ 8.39. The soil porosity is about $40 \%$ and capillary porosity is $32 \%$. The mean groundwater depth over the past 9 years (2001-2009) was $16.5 \pm 0.2 \mathrm{~m}$, and declined at an average rate of $0.6 \mathrm{~m}$ per year. The maximum pan evaporation occurs from May through June, exceeding precipitation for the same period. Severe drought during the beginning of the growing season (from April to June) in northern China is common. The site was irrigated using pumped groundwater, and the amount of water supplied was estimated from the water meter records at the three adjacent wells on a weekly basis from 2006 through 2009. Other management practices have included tilling and weeding since the establishment of the plantations.

\subsection{Eddy covariance system}

The micrometeorological and eddy flux measurements were conducted at a $32 \mathrm{~m}$ tower in the center of the study site, which was established in June 2005. The footprint of the 
Table 1. The stand characteristics of 4 years from 2006 to 2009, including the minimum, maximum, and mean temperature ( $T$ ), the annual precipitation $(P)$, evapotranspiration $(\mathrm{ET})$, irrigation $(I)$, canopy height $(H)$, breast height diameter $(\mathrm{DBH})$, and leaf area index $(\mathrm{LAI})$. The error estimates are standard deviation (SD).

\begin{tabular}{rrrrrrrrrr}
\hline & $T_{\min }$ & $\begin{array}{r}T_{\max } \\
\left({ }^{\circ} \mathrm{C}\right)\end{array}$ & $T_{\text {mean }}$ & $\begin{array}{r}P \\
(\mathrm{~mm})\end{array}$ & $\begin{array}{r}\mathrm{ET} \\
(\mathrm{mm})\end{array}$ & $\begin{array}{r}I \\
(\mathrm{~mm})\end{array}$ & $\begin{array}{r}H \\
(\mathrm{~m})\end{array}$ & $\begin{array}{r}\mathrm{DBH} \\
(\mathrm{cm})\end{array}$ & $\begin{array}{r}\text { LAI } \\
\left(\mathrm{m}^{2} \mathrm{~m}^{-2}\right)\end{array}$ \\
\hline 2006 & -10.6 & 29.7 & $12.5 \pm 0.73$ & 482 & 599 & 86 & $11.5 \pm 1.1$ & $10.8 \pm 1.5$ & $1.6 \pm 0.3$ \\
2007 & -9.8 & 29.5 & $13.0 \pm 0.55$ & 667 & 560 & - & $13.0 \pm 1.3$ & $12.2 \pm 1.8$ & $2.1 \pm 0.4$ \\
2008 & -7.4 & 28.8 & $13.3 \pm 0.54$ & 662 & 653 & - & $14.8 \pm 1.2$ & $13.8 \pm 1.8$ & $2.2 \pm 0.7$ \\
2009 & -10.2 & 30.5 & $12.5 \pm 0.60$ & 428 & 511 & 195 & $16.2 \pm 1.6$ & $14.5 \pm 1.6$ & $2.9 \pm 0.4$ \\
\hline
\end{tabular}

eddy flux covariance system, was about $1 \mathrm{~km} \times 1 \mathrm{~km}$ in size, with a fetch of at least $300 \mathrm{~m}$ in all directions. Fluxes of $\mathrm{CO}_{2}$, sensible heat, and latent heat were calculated based on eddy-covariance (EC) principles. The sensors included a $\mathrm{CO}_{2} / \mathrm{H}_{2} \mathrm{O}$ infrared analyzer (Li-7500; LI-COR, Inc., Lincoln, NE, USA) and a three-dimensional sonic anemometer (CSAT-3; Campbell Scientific, Inc., CSI, UT, USA). The anemometer head was installed towards a predominant wind direction (southeast), and the IRGA was installed at a slight vertical angle tilted northward $\left(<20^{\circ}\right)$ between the sonic path and anemometer body. The IRGA was calibrated every year. The EC sensors were mounted initially at a height of $16 \mathrm{~m}$ in 2006. This was increased to about $18 \mathrm{~m}$ before the start of the growing season in 2007, and again to $20 \mathrm{~m}$ in February 2009 to ensure that the sensors remained well above the tree canopy.

Net radiation was measured with net radiometers (Q7.1, REBS, Seattle, WA, USA) and (CNR-1; Kipp and Zonen, Delft, Netherlands) at $26 \mathrm{~m}$ above the ground. Photosynthetically active radiation (PAR) was measured with a PAR quantum sensor (LI-190SB; LI-COR, Inc.) mounted at $20 \mathrm{~m}$. The atmospheric pressure was measured by a barometric pressure sensor (CS105, CSI) at a height of $21 \mathrm{~m}$. Air temperatures and humidity were measured with a temperature and relative humidity probe (HMP45C; Vaisala, Helsinki, Finland) at 5, 10,15 , and $20 \mathrm{~m}$ above ground. Precipitation was measured with a tipping bucket rain gauge (TE525-L; Texas Electronics, USA) at $22.5 \mathrm{~m}$. Soil heat flux and soil temperatures were each measured with three soil heat transducers (HFT3, CSI) and three thermocouples (TCAV107; CSI) located at depths of 5,10 , and $20 \mathrm{~cm}$ below the soil surface. Soil water content was measured with TDR sensors (CS616; CSI) buried at 20 and $50 \mathrm{~cm}$.

With the exception of the rain gauge, all microclimatic data were recorded with a data-logger (CR23X; CSI) at 30 min intervals and the fluctuations in wind speed, sonic temperature and $\mathrm{CO}_{2}$ and $\mathrm{H}_{2} \mathrm{O}$ concentrations were sampled at $10 \mathrm{~Hz}$ and recorded by a CR5000 data-logger (CSI).

\subsection{3. Data processing and QA/QC}

The 30 min mean fluxes were calculated from raw $10 \mathrm{~Hz}$ data with an EC Processor software, version 2.3 (Noormets et al.,
2010). The program is designed for reprocessing EC flux data and can calculate half-hour mean eddy-covariance fluxes of carbon, water, and energy. The wind coordinates were rotated using the planar fit method (Paw U et al., 2000; Wilczak et al., 2001). Fluxes were corrected for additional sensor heating (Burba et al., 2008) and fluctuations in air density (Webb et al., 1980). The data quality controls included: screening of the 30 min mean eddy-covariance fluxes based on instrument quality flag, integral turbulence characteristics (Foken and Wichura, 1996), flux stationarity, atmospheric stability, and adequate turbulent mixing (Goulden et al., 1996). The threshold of friction velocity $\left(\mu_{*}\right)$ below which flux loss occurred was determined from the seasonal binned relationship between nighttime turbulent flux of $\mathrm{CO}_{2}$ and friction velocity ( $\mu_{*}$; Schmid et al., 2003). The threshold was consistent across different seasons, but differed slightly between years: 0.18 (2006), 0.12 (2007), 0.14 (2008) and $0.13 \mathrm{~m} \mathrm{~s}^{-1}$ (2009). Data gaps shorter than $2 \mathrm{~h}$ were filled using linear regressions between the flux of interest and net radiation $\left(R_{\mathrm{n}}\right)$, gaps between $2 \mathrm{~h}$ and 7 days in length were filled using the mean diurnal variation (MDV) method (Falge et al., 2001), and gaps longer than 7 days were not filled.

The 4-year study period was distinctively classified into "wet" and "dry" years. A dry year referred to a year with annual precipitation less than $85 \%$ of the 20 -year average according to the National Standard of the People's Republic of China (GB/T 20481-2006; China, 2006) and "wet" when above this average. Years 2007 and 2008 were classified as 'wet' while 2006 and 2009 were 'dry' years. We focused on the growing season when the environmental forcing (e.g., solar radiation and temperature) for energy and water fluxes and the physiological response of vegetation were usually strong. In this study, the strongest forcing days occurred approximately between day 100 (mid-April) and day 300 (late October). The daytime was defined as the period between sunrise and sunset with PAR $>4 \mu \mathrm{mol} \mathrm{m}{ }^{-2} \mathrm{~s}^{-1}$. The regulation of surface energy and gas exchange is often different during nocturnal periods (Mahrt, 1999), with heat fluxes at night typically weaker and markedly less stationary than during the daytime (Wilson et al., 2002b). Midday was defined as the period from 10:00 to 15:00 LST when the coupling between vegetation and the atmosphere was the strongest. 


\subsection{Biophysical characteristics}

The availability of relative extractable water (REW) content was calculated to analyze the ecosystem response to drought stress. According to Granier et al. (2007), soil water stress was assumed to occur when the REW dropped below the threshold of 0.4. Daily REW is calculated as

$\mathrm{REW}=\frac{\mathrm{VWC}-\mathrm{VWC}_{\min }}{\mathrm{VWC}_{\max }-\mathrm{VWC}_{\min }}$,

where $\mathrm{VWC}_{\min }$ and $\mathrm{VWC}_{\max }$ are the minimum and maximum soil volumetric water content, respectively, across the 4 years.

The Bowen ratio $(\beta)$ reflects the influence of microclimate and the hydrological cycle on the energy partitioning and water use of the ecosystem (Perez et al., 2008). The midday $\beta$ is calculated as Eq. (2):

$\beta=\frac{H}{\mathrm{LE}}$.

Based on the daytime half-hourly and daytime totals of turbulent energy fluxes, the energy balance ratio $\left(E_{\mathrm{BR}}\right)$ is calculated as Eq. (3):

$E_{\mathrm{BR}}=\frac{\sum(H+\mathrm{LE})}{\sum\left(R_{\mathrm{n}}-G-S\right)}$,

where $S$ is the latent and sensible heat storage in the aircolumn below the EC system and is calculated as in Eq. (4) (Dou et al., 2006):

$S=\int_{0}^{\mathrm{hc}} \rho c_{p} \frac{\partial T}{\partial t} \mathrm{~d} z+\int_{0}^{\mathrm{hc}} \frac{\rho c_{p}}{\gamma} \frac{\partial e}{\partial t} \mathrm{~d} z$,

where hc is the height of the eddy flux system measurement (32 $\mathrm{m}), T$ is air temperature in the air-column below hc, and $e$ is water vapor pressure.

During midday periods (10:00-15:00 LST), the PenmanMonteith approximation was inverted to calculate the surface resistance $\left(R_{\mathrm{S}}\right)$ in Eq. (5) (Kumagai et al., 2004):

$R_{\mathrm{S}}=\frac{\rho c_{p}\left(\delta_{e} / \mathrm{LE}\right)}{\gamma}+\left(\frac{\Delta}{\gamma} \beta-1\right) R_{\mathrm{a}}$,

where $R_{\mathrm{S}}$ is the surface resistance to water vapor transport $\left(\mathrm{s} \mathrm{m}^{-1}\right)$, representing four components: bulk stomatal resistance of the canopy, bulk boundary layer resistance of the vegetation, bulk ground resistance, and bulk boundary layer resistance of the ground (Admiral et al., 2006; Cho et al., 2012; Perez et al., 2008; Wilson et al., 2002b).

$R_{i}$ is the climatological resistance $\left(\mathrm{s} \mathrm{m}^{-1}\right)$ indicating the atmospheric demand (Wilson et al., 2002b) and is calculated as

$R_{i}=\frac{\rho c_{p} \delta_{e}}{\gamma A}$, where $A$ is the available energy $\left(R_{\mathrm{n}}-G\right) ; \rho$ is air density $\left(\mathrm{kg} \mathrm{m}^{-3}\right), c_{p}$ is the specific heat of the air $\left(1005 \mathrm{~J} \mathrm{~kg}^{-1} \mathrm{~K}^{-1}\right)$; $\delta_{e}$ is the atmospheric vapor pressure deficit (Pa); LE is the latent heat flux; $\Delta$ is the change of saturation vapor pressure with temperature $\left(\mathrm{Pa} \mathrm{K}^{-1}\right) ; \gamma$ is the psychrometric constant $\left(\approx 67 \mathrm{~Pa} \mathrm{~K}^{-1}\right)$; and $\beta$ is the Bowen ratio.

$R_{\mathrm{a}}$ is the aerodynamic resistance of the air layer between the canopy and the flux measurement height $\left(\mathrm{s} \mathrm{m}^{-1}\right)$, that reflects the aerodynamic properties of turbulent transport in the near-surface boundary layer (Holwerda et al., 2012; Zhang et al., 2007). $R_{\mathrm{a}}$ is calculated following Hossen et al. (2011) and Migliavacca et al. (2009):

$R_{\mathrm{a}}=r_{\mathrm{a}, \mathrm{m}}+r_{b}=\frac{\mu}{\mu_{*}^{2}}+6.2 \mu_{*}^{-2 / 3}$,

where $r_{\mathrm{a}, \mathrm{m}}$ is the aerodynamic resistance for momentum transfer, $r_{b}$ is the quasi-laminar boundary-layer resistance, $\mu$ is the wind speed, and $\mu_{*}$ is the friction velocity.

The decoupling coefficient $(\Omega)$ explains the degree of coupling between the atmosphere and the vegetation, and describes the relative control of evapotranspiration by surface resistance and net radiation (Pereira, 2004). The $\Omega$ value ranges from 0 to 1 , with values approaching zero indicating that LE is highly sensitive to surface resistance and ambient humidity deficit. The $\Omega$ value approaching 1 indicates that LE or evapotranspiration is mostly controlled by net radiation (Jarvis and McNaughton, 1986):

$\Omega=\frac{\Delta+\gamma}{\Delta+\gamma\left(1+\frac{R_{\mathrm{s}}}{R_{\mathrm{a}}}\right)}$.

The equilibrium evaporation ( $\mathrm{LE}_{\mathrm{eq}}$ ) is the climatologically determined evaporation (atmospheric demand) over an extensive wet surface and is dependent only on $R_{\mathrm{n}}$ and temperature. It is calculated as

$\mathrm{LE}_{\mathrm{eq}}=\frac{\Delta\left(R_{\mathrm{n}}-G\right)}{\Delta+\gamma}$.

The ratio LE / $L E_{\text {eq }}$, which is also known as the PriestleyTaylor $\alpha$, reflects the control of evaporation by atmospheric and physiological factors. $\mathrm{LE} / \mathrm{LE}_{\mathrm{eq}}$ characterizes the surface dryness of an ecosystem, indicating whether soil water supply for evapotranspiration of an ecosystem was limited. An $\mathrm{LE} / \mathrm{LE}_{\mathrm{eq}}$ of $<1$ indicates water stress and suppressed evapotranspiration. Conversely, $\mathrm{LE} / \mathrm{LE}_{\mathrm{eq}}>1.26$ indicates unrestricted water supply, and only available energy limits evapotranspiration (Arain et al., 2003). The LE / LE eq is dependent on the leaf area index (LAI), soil water content, meteorological conditions (e.g., wind speed, solar radiation, VPD (vapor pressure deficit, air stratification stability, convection, and advection surface resistance), vegetation types, and altitude (Guo et al., 2008).

\subsection{Statistical analysis}

Repeated ANOVA (SPSS) measurements were used for quantifying the changes of all the biophysical variables, en- 


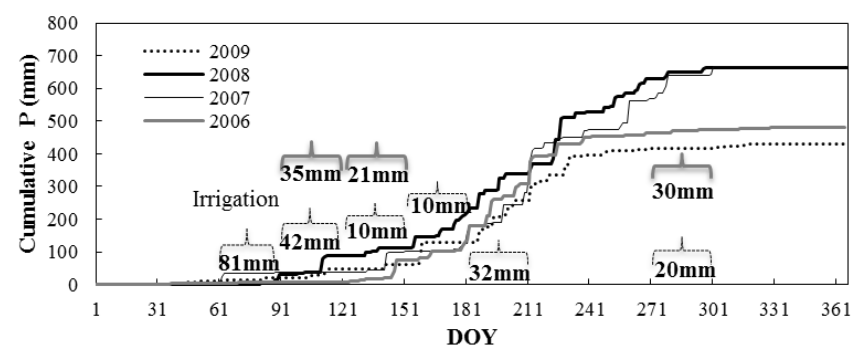

Figure 1. The cumulative precipitation $(P)$ and periodic irrigation during 2006-2009; irrigation in 2006 and 2009 were separately represented by the solid and dotted brackets, respectively.

ergy fluxes, and bulk parameters across years. The $t$ test was used to compare the differences of biophysical variables among different studies. The partial correlation analysis was used to distinguish the impacts of each of the three resistance parameters $\left(R_{\mathrm{s}}, R_{i}\right.$, and $\left.R_{\mathrm{a}}\right)$ on the Bowen ratios. All analyses were accessed at $\alpha=0.05$.

\section{Results}

\subsection{Environmental conditions}

The annual precipitation rates in the 4 years of study differed from the long-term (i.e., 1990-2009) average (556 $\mathrm{mm} \mathrm{yr}^{-1}$ ). Thus, years 2006 and 2009 were drier and 2007 and 2008 were wetter than the mean (Table 1). The interannual contrast was exaggerated by the seasonality of rainfall. Generally, over $90 \%$ precipitation of each year occurred in AprilOctober, but with different timing and magnitude among the years. The study site was irrigated during the dry years of 2006 and 2009 to mitigate drought conditions (Fig. 1). Seasonal drought stress (REW < 0.4 ) occurred during periods in the late growing season of 2006 and 2009, the spring of 2007 and 2009, but not at all in 2008 (Fig. 2a-d). In 2006, precipitation during the growing season reached $467 \mathrm{~mm}$, of which $51 \%$ had occurred by July. The amount of irrigation was $35 \mathrm{~mm}$ in April, $21 \mathrm{~mm}$ in May, and $30 \mathrm{~mm}$ in September. The two separate seasonal drought periods were \#1_06 (from DOY - day of year - 164 to 192) and \#2_06 (from DOY 231 to 300 ). The total rainfall in 2007 and 2008 was similar, but more evenly distributed throughout the year in 2008. In 2007, drought stress occurred during DOY 110-143 (\#1_07) and 151-200 (\#2_07). A single rain event in late May $(57 \mathrm{~mm})$ and a few large precipitation events $\left(>25 \mathrm{~mm} \mathrm{~d}^{-1}\right)$ in July were recorded. The amount of rainfall in 2009 was the smallest among the 4 years, during which $195 \mathrm{~mm}$ of irrigation was applied from March to September. There were several short and scattered droughts across the growing season in 2009 (Fig. 2d). Despite the higher than normal rainfall in the 2 wet years, there was no flooding or overland runoff.

The growing season $T_{a}$ in 2008 was significantly lower than in 2007 and $2009\left(\mathrm{~d} T=1.3{ }^{\circ} \mathrm{C}, p<0.05\right.$, Fig. 2e- h). The years differed in the spring warm-up and the timing of peak temperature (by up to $35.9^{\circ} \mathrm{C}$ ). The maximum air temperature occurred in June 2006 and 2009, and in July 2007 and 2008. The warmest month was June 2006 $\left(27.1 \pm 2.4^{\circ} \mathrm{C}\right)$.

The daytime average VPD of the four growing seasons (Fig. 2e-h) was $1.3 \pm 0.7 \mathrm{kPa}$. The mean VPD in wet years (i.e., 2007 and 2008) was $1.2 \pm 0.7 \mathrm{kPa}$, which was significantly lower $(F=6.093, p<0.01)$ than in dry years (i.e., 2006 and 2009, $1.3 \pm 0.8 \mathrm{kPa}$ ). The VPD of the growing season in 2008 (i.e., $1.1 \pm 0.5 \mathrm{kPa}$ ) was lower than in the other years $(p<0.05)$. Higher $T_{a}$ and lower precipitation in May 2007 led to higher VPD compared to the same period in 2006 and $2008(p<0.001)$. Furthermore, the VPD was the highest in June 2009 (i.e., $2.3 \pm 1.1 \mathrm{kPa}, p<0.05$ ) and the lowest in 2008 (i.e., $1.0 \pm 0.5 \mathrm{kPa}, p<0.01$ ).

\subsection{Seasonal changes in energy partitioning and $\beta$}

The energy partitioning trends of daytime total net radiation $\left(R_{\mathrm{n}}\right)$ into latent, sensible heat fluxes (LE and $\left.H\right)$, soil heat fluxes $(G)$, and heat storage of canopy $(S)$ for the years 2006-2009 were presented in Fig. 3. Among these years, $R_{\mathrm{n}}$ varied with solar radiation $(R>0.95, \alpha=0.01$ level $)$, reached the maximum in July, and gradually decreased until late October (in dry years) or November (in wet years). During the growing season, there were no significant differences in average daytime total $R_{\mathrm{n}}$ between wet and dry years. The average daytime total $G$ during the growing season displayed great seasonal and annual differences among the years $(p<0.05)$, with a lower value in wet years $(2.1 \%$ in 2007$)$ than in the dry years $(4.9 \%$ in $2006 ; p<0.001)$. Moreover, the average values of daytime total $S$ among the four growing seasons were $0.46,0.49,0.51$, and $0.54 \mathrm{MJ} \mathrm{m}^{-2}$, respectively. $S / R_{\mathrm{n}}$ varied from $6.0 \%$ in 2007 to $6.8 \%$ in 2009, showing no differences between the wet and dry years.

Partitioning of $R_{\mathrm{n}}$ into LE and $H$ differed significantly between the wet and dry years (Table 3; $F=17.599$, $p<0.001)$. The dominant turbulent energy flux during the early growing season was sensible heat flux $(H)$ with or without drought stress, except in 2006 when the irrigation was applied (Table 3). Then LE was the dominant driver of energy partitioning during the middle and late growing seasons under drought stress. The average daytime total LE was about $20 \%$ greater in wet years $\left(6.77 \mathrm{MJ} \mathrm{m}^{-2}\right)$ than in dry years $\left(5.72 \mathrm{MJ} \mathrm{m}^{-2}, p<0.01\right)$. The timing of peak LE was weakly related to drought, peaking in July in 2006, 2008, and 2009, and in August in 2007. The peak values of daytime total LE were 16.61, 17.01, 19.72, and $16.27 \mathrm{MJ} \mathrm{m}^{-2}$, in 2006-2009 respectively. The daily evaporative fraction $\left(\mathrm{LE} /\left(R_{\mathrm{n}}-G\right)\right)$ was significantly higher in wet years $(60.3$ and $64.8 \%$ in 2007 and 2008, respectively) than in dry years (57.1 and 50.4\% in 2006 and 2009, respectively; $p<0.05$ ).

The seasonal variation of the midday Bowen ratio $(\beta)$ displayed a rapid and significant trend across the growing sea- 

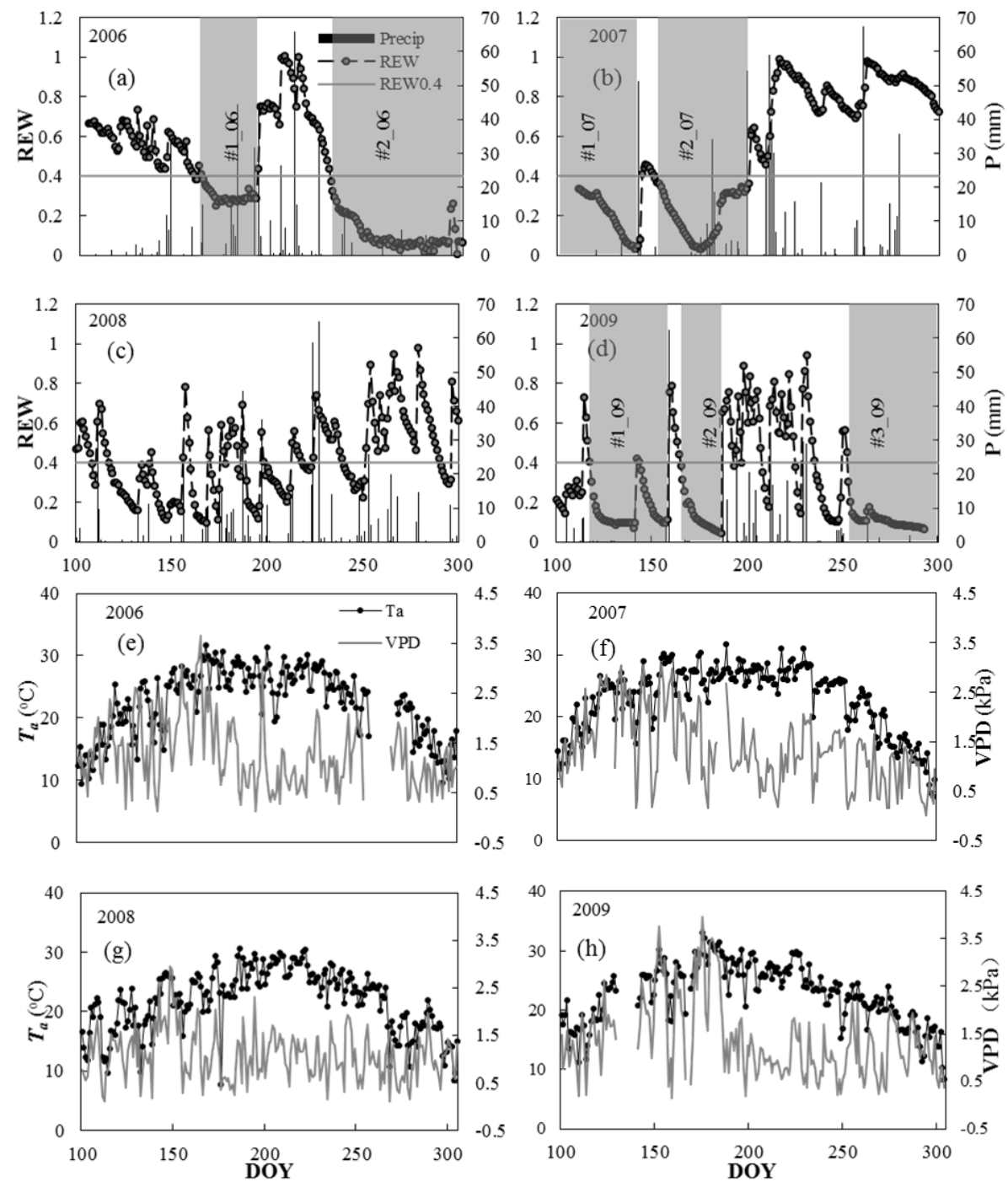

Figure 2. The seasonal variation of environmental conditions during 2006-2009, (a-d) the relative extractable water (REW; drought periods longer than 20 days are shaded), daily sum of precipitation $(P) ;(\mathbf{e}-\mathbf{h})$ daytime mean air temperature $\left(T_{\mathrm{a}}\right)$, daytime mean air vapor deficit (VPD).

son, especially at the beginning (April-June) and the end (September-October) of the growing season (Fig. 4). The Bowen ratios during the middle of the growing seasons were all smaller than 1, and approximately lasted from DOY 180 250 in the dry year and from DOY 180-290 in the wet years. The average midday $\beta$ in the dry years was greater (1.57) than in the wet years $(0.83 ; F=19.176, p<0.001)$. The Bowen ratio showed differences in response to drought stress across the four growing seasons (Table 3); with much higher values (>1) during the drought periods in 2007 and 2009, but not in 2006. The Bowen ratio was smaller than 1 during drought-stressed periods in 2008.

\subsection{Biophysical controls of energy partitioning}

The $R_{\mathrm{S}}$ varied widely at the beginning and the end of growing season, but changed steadily within a low range during the middle of growing season by comparison. Moreover, these lower $R_{\mathrm{S}}$ values in the dry years lasted for a shorter period (DOY 190-250) than in the wet years (Fig. 5a). A significantly negative relationship was found between the $R_{\mathrm{S}}$ and LAI during the wet years (Fig. 6). Overall, the seasonal average of $R_{\mathrm{S}}$ normalized by leaf area index (LAI; i.e., $R_{\mathrm{s}}: \mathrm{LAI}$ ) was lowest during the wettest year $\left(2008,54.1 \mathrm{~s} \mathrm{~m}^{-1} \mathrm{LAI}^{-1}\right.$; $p<0.05)$. The $R_{\mathrm{s}}: \mathrm{LAI}$ in the dry years $\left(106.8 \mathrm{~s} \mathrm{~m}^{-1} \mathrm{LAI}^{-1}\right)$ was $50 \%$ higher than in the wet years $\left(71.2 \mathrm{~s} \mathrm{~m}^{-1} \mathrm{LAI}^{-1}\right.$; $p<0.001)$. The $R_{\mathrm{S}}:$ LAI in the seasonal drought-stressed pe- 

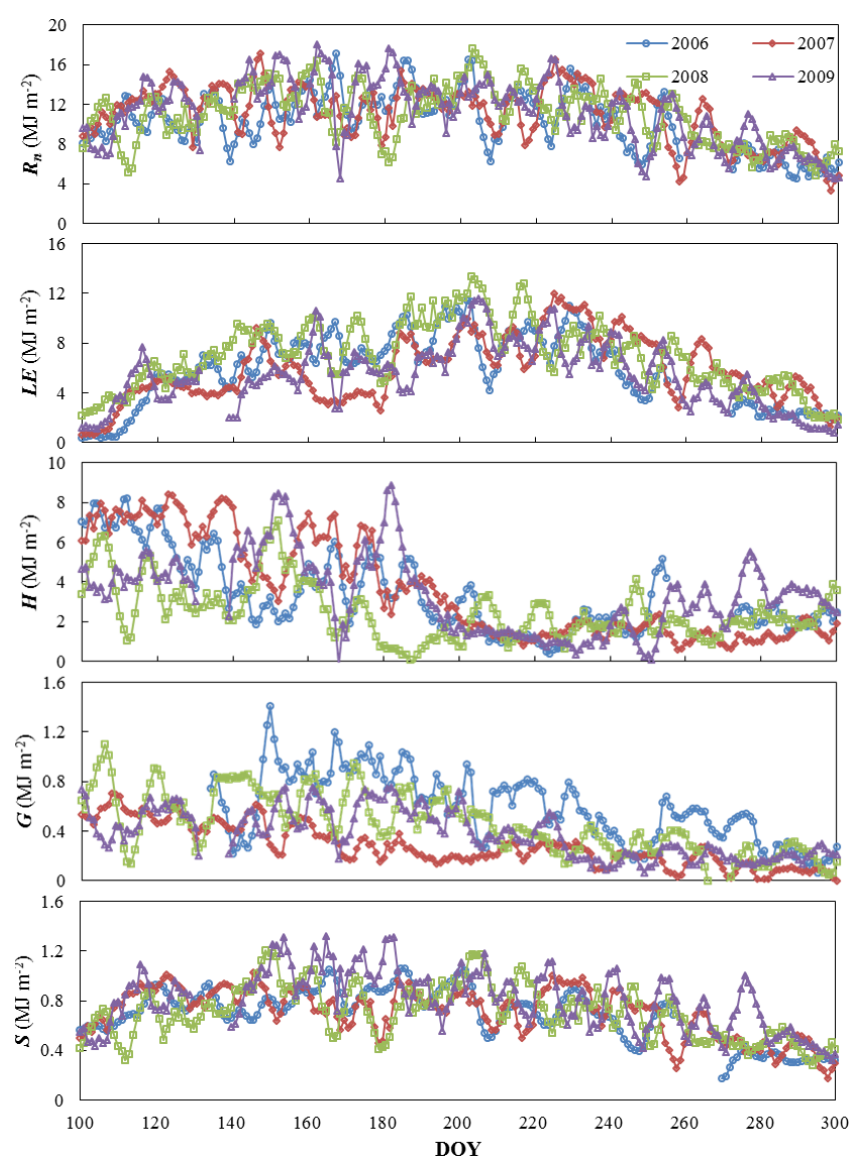

Figure 3. Seasonal patterns of daytime energy components (5-day running average) during the growing seasons from 2006 to 2009, including net radiation $\left(R_{\mathrm{n}}\right)$, latent heat (LE), sensible heat $(H)$, soil heat flux $(G)$, and heat storage term $(S)$.

riods in 2006, 2007, and 2009 were much higher than those during unstressed periods $(p<0.001$, Table 3$)$.

The average midday $R_{i}$ peaked in June and decreased in July/August before reaching a second peak in October (Fig. 5b). The seasonal average $R_{i}$ during the growing season ranged from 68.3 to $77.9 \mathrm{~s} \mathrm{~m}^{-1}$, with a mean value of $74.4 \mathrm{~s} \mathrm{~m}^{-1}$, and showed no difference among the four growing seasons $(p>0.05)$. Figure $5 c$ presents the seasonal and annual variations of midday $R_{\mathrm{a}}$. The average $R_{\mathrm{a}}$ for the four growing seasons was $23.2 \pm 8.5 \mathrm{~s} \mathrm{~m}^{-1}$, ranging from 10.6 to 43.5, 9.7 to $52.5,6.5$ to 43.1 , and 9.7 to $74.5 \mathrm{~s} \mathrm{~m}^{-1}$, from 2006 to 2009 , respectively. $R_{\mathrm{a}}$ in 2007 was significantly higher than in the dry years $(p<0.01)$, while $R_{\mathrm{a}}$ in 2008 was smaller than in the dry years $(p<0.001)$. However, there were no significant differences between dry and wet years $R_{\mathrm{a}}$ $(p>0.05)$.

The seasonal changes of $\mathrm{LE} / \mathrm{LE}_{\mathrm{eq}}$ values varied between 0.4 and 1.0 during most of the growing seasons (Fig. 5d). The average $\mathrm{LE} / \mathrm{LE}_{\text {eq }}$ of the 4 years were $0.76,0.73,0.89$, and 0.63 , respectively. The mean $\mathrm{LE} / \mathrm{LE}_{\mathrm{eq}}$ of the dry years

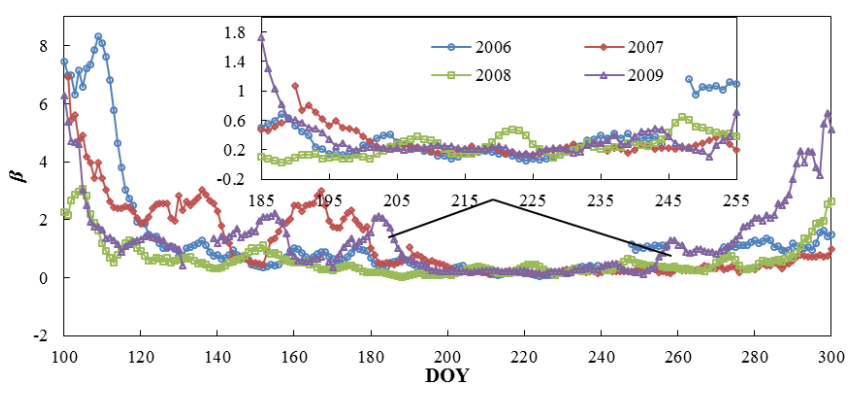

Figure 4. Seasonal and inter-annual variability of the midday (10:00-15:00 LST) mean Bowen ratio $(\beta ; 5$-day running average) across the growing seasons, with detailed $\beta$ during DOY 185-255 represented in the small pane.

(0.68) was lower than that of wet years $(0.81 ; p<0.001)$. Specifically, the value of $L E / L E_{\text {eq }}$ in drought periods of 2007 and 2009 were much smaller. A significantly exponential relationship existed between the $\mathrm{LE} / \mathrm{LE}_{\mathrm{eq}}$ and $R_{\mathrm{S}}$ during the growing season (Fig. 7).

The decoupling coefficient $(\Omega)$ across the growing seasons peaked in mid-July in 2008 and in early August in the other years (Fig. 5e). The mean $\Omega$ for the 4 years was $0.41,0.46$, 0.43 , and 0.39 (Table 3), respectively, and was significantly higher in wet years $(0.45)$ than in dry years $(0.40 ; F=9.460$, $p<0.01)$. Compared to the value during unstressed periods, the decoupling coefficient during the seasonal drought periods (\#1_06, \#2_06; \#1_07, \#2_07 and \#1_09, \#2_09, \#3_09) was much lower in value.

\section{Discussion}

\subsection{Energy partitioning and Bowen ratio}

The energy balance ratio $\left(E_{\mathrm{BR}}\right)$ in the current study was 0.88 based on daytime 30-min fluxes and $>0.96$ based on daytime totals (Table 2). The annual mean $E_{\mathrm{BR}}$ at our site was similar to the values of eight ChinaFlux sites, which averaged 0.83 and ranged from 0.58 to 1.00 ( $\mathrm{Li}$ et al., 2005). The energy budget is also consistent with the 50 site-years of flux data from 22 FLUXNET sites, which had energy closure of 0.341.69 (Mean $=0.84$, Wilson et al., 2002a). A recent analysis of 173 FLUXNET sites also found an average closure of 0.84 (Stoy et al., 2013), although the authors also detected consistent differences among the biomes based on metrics of landscape heterogeneity. In addition to the known reasons for decreasing energy balance closure (Hernandez-Ramirez et al., 2010; Li et al., 2005; Nakai et al., 2006; Stoy et al., 2013), management operations at our site (e.g., irrigation, tilling, and partial felling) may also affect the energy balance. Although the causes of surface energy balance closure continue to be debated (Stoy et al., 2013) and will not be conclusively answered in the current study, the results reported here are similar to other FLUXNET sites. 
Table 2. Energy balance closure statistics using half-hourly and daytime totals during growing seasons from 2006 to 2009.

\begin{tabular}{lrrrrrrrr}
\hline & \multicolumn{4}{c}{ Daytime } & \multicolumn{5}{c}{ Daytime sum } \\
\cline { 2 - 8 } & 2006 & 2007 & 2008 & 2009 & 2006 & 2007 & 2008 & 2009 \\
\hline Slope & 0.92 & 0.87 & 0.92 & 0.82 & 1.07 & 0.91 & 1.04 & 0.84 \\
Intercept & 20.50 & 17.24 & 10.72 & 13.08 & -0.63 & -0.09 & -0.79 & -0.30 \\
$R^{2}$ & 0.81 & 0.80 & 0.81 & 0.82 & 0.88 & 0.81 & 0.92 & 0.82 \\
\hline
\end{tabular}

Daytime was defined as the period between sunrise and sunset with PAR $>4 \mu \mathrm{mol} \mathrm{m}{ }^{-2} \mathrm{~s}^{-1}$; the unit of intercept for half-hourly values and the daytime sum value were $W \mathrm{~m}^{-2}$ and $\mathrm{MJ} \mathrm{m}^{-2}$, respectively.
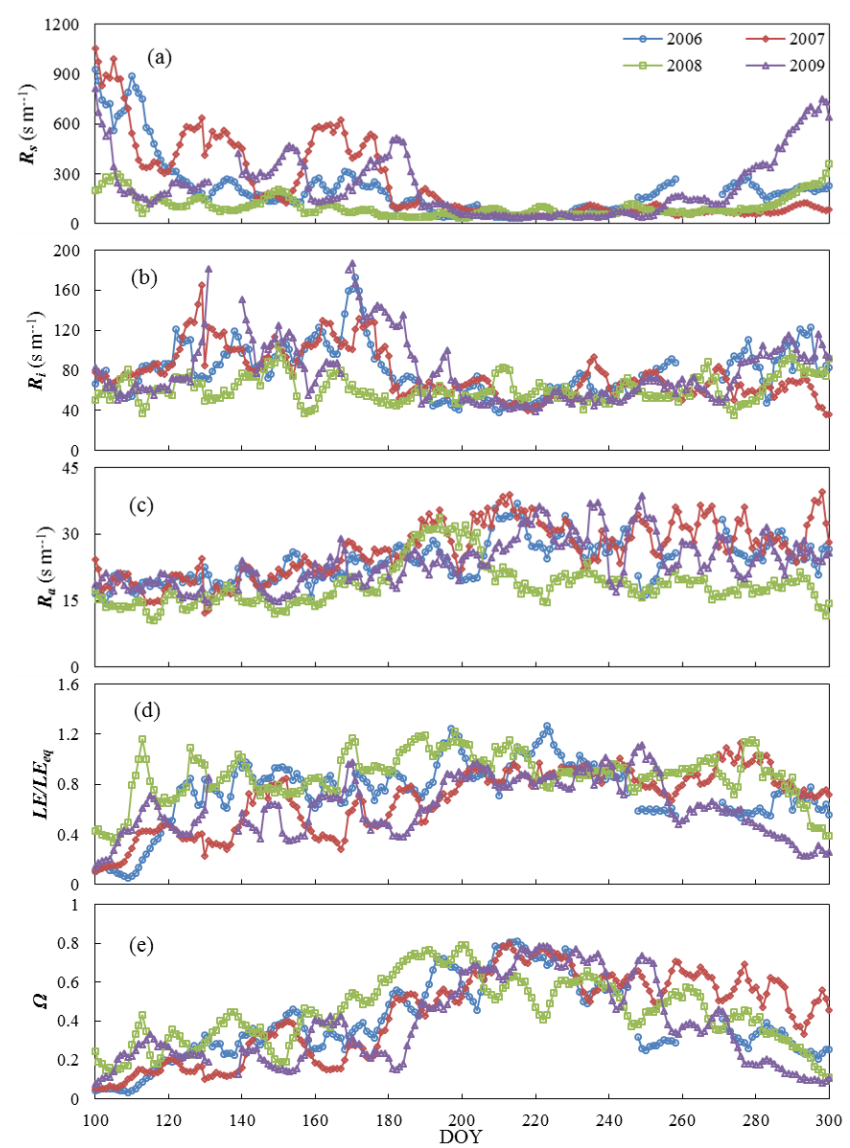

Figure 5. Seasonal dynamics of the midday (10:00-15:00 LST) mean surface resistance $\left(R_{\mathrm{S}}\right)$, climatological resistance $\left(R_{i}\right)$, aerodynamic resistance $\left(R_{\mathrm{a}}\right), \mathrm{LE} / \mathrm{LE}_{\mathrm{eq}}$, and decoupling coefficient $(\Omega)$ (5-day running average) across the growing seasons from 2006 to 2009.

The surface energy partitioning to sensible and latent heat depends on water potential gradient and surface resistance (Arain et al., 2003; Baldocchi et al., 2000; Chen et al., 2009). Canopy development (Guo et al., 2010), rainfall dynamics and irrigation (Ozdogan et al., 2010) affect these properties to some extent and could directly lead to a change in soil moisture and the evaporation component of LE, thereby impacting energy partitioning and $\beta$ (Chen et al., 2009; Ozdo-

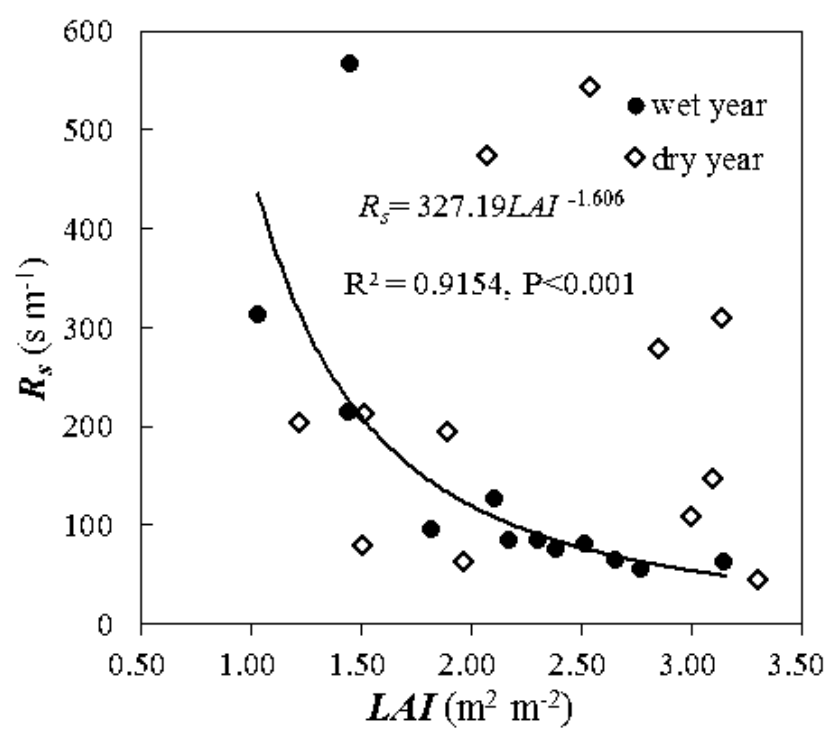

Figure 6. The relationship between leaf area index (LAI) and surface resistance $\left(R_{\mathrm{S}}\right)$ during the growing season of the wet and dry years.

gan et al., 2010). However, the impact of precipitation on the Bowen ratio may vary, even at the same site (Tang et al., 2014). In our study, detectable responses of $\mathrm{LE} /\left(R_{\mathrm{n}}-G\right)$ and the Bowen ratio to drought stress and non-stress periods were observed in response to soil water supply (Table 3) with a $50 \mathrm{~mm}$ threshold on average (Fig. 8). The variability of energy partitioning during the growing season was highly sensitive to water availability from precipitation and irrigation. On an annual scale, the Bowen ratio appeared linearly related to the total growing season precipitation $\left(R^{2}=0.89\right.$, $p<0.05)$. Thus, the Bowen ratio is very responsive to the site water supply. A similar finding was reported by Grünwald and Bernhofer (2007) in a temperate spruce forest.

By contrast, $\beta$ varied from 0.18 to 0.71 , with a mean of $0.35 \pm 0.15$ during most of the growing season in 2008 and in the non-stressed periods of the other 3 years. This variation was close to 0.42 for deciduous forests (Wilson et al., 2002b) and 0.55 in a temperate Douglas fir (Humphreys et al., 2003), which is also similar to the variations in a ponderosa pine forest in the western United States (Goldstein et al., 2000) and 

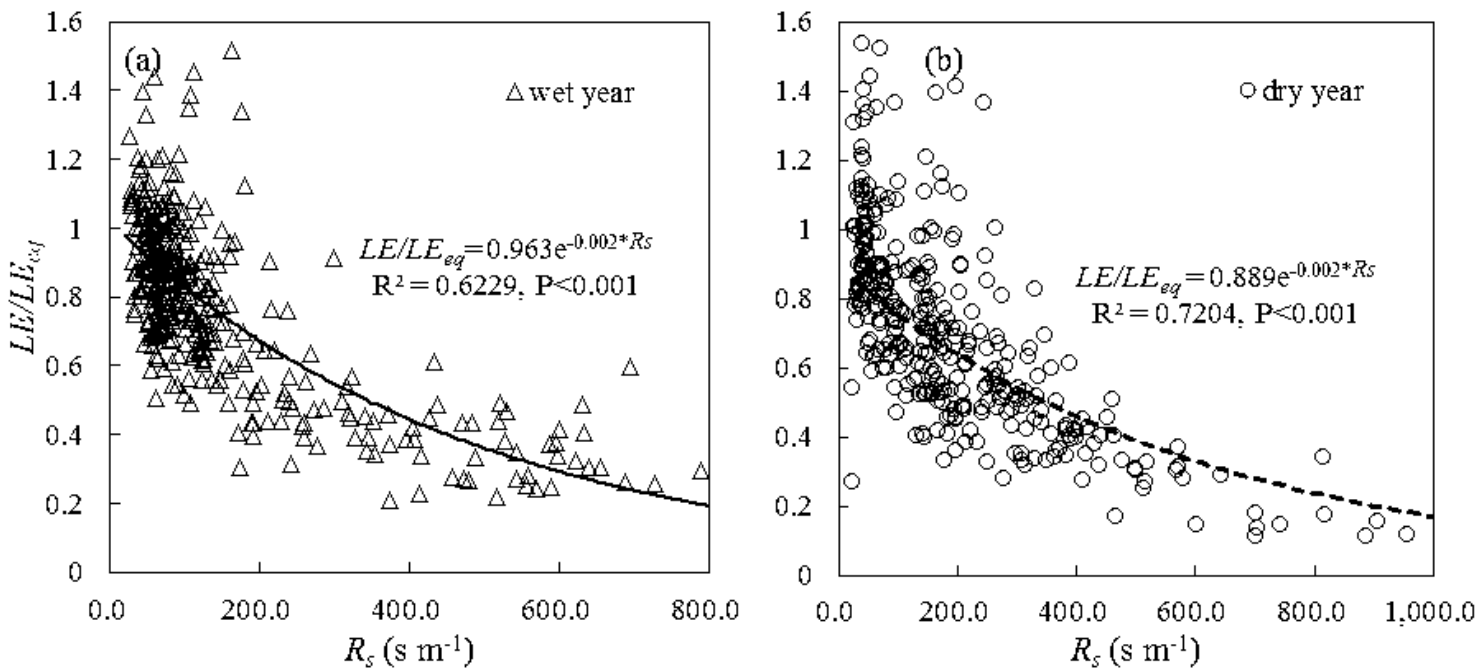

Figure 7. The relationships between surface resistance $\left(R_{\mathrm{S}}\right)$ and $\mathrm{LE} / \mathrm{LE}$ eq (Priestley-Taylor coefficient) during growing season of the wet (a) and dry (b) year.

Table 3. The value of the soil water supply (WS), energy partitioning ratios, and biophysical variables in the different growing seasons during 2006-2009.

\begin{tabular}{|c|c|c|c|c|c|c|c|c|c|c|}
\hline Year & $\begin{array}{r}\text { Periods } \\
\text { (DOY) }\end{array}$ & $\begin{array}{r}\text { WS } \\
(\mathrm{mm})\end{array}$ & $\begin{array}{r}\mathrm{LE} /\left(R_{\mathrm{n}}-G\right) \\
(\%)\end{array}$ & $\begin{array}{r}H /\left(R_{\mathrm{n}}-G\right) \\
(\%)\end{array}$ & $\beta$ & $\begin{array}{r}R_{\mathrm{S}} \\
\left(\mathrm{s} \mathrm{m}^{-1}\right)\end{array}$ & $\begin{array}{r}R_{i} \\
\left(\mathrm{~s} \mathrm{~m}^{-1}\right)\end{array}$ & $\begin{array}{r}R_{\mathrm{a}} \\
\left(\mathrm{s} \mathrm{m}^{-1}\right)\end{array}$ & $\alpha$ & $\Omega$ \\
\hline \multirow{4}{*}{2006} & $100-163$ & $76.2+56$ & $50.5(23.4)$ & $45.9(19.7)$ & $3.48(6.37)$ & 418.7 (528.7) & $87.8(30.2)$ & $20.0(6.3)$ & $0.64(0.35)$ & $0.25(0.13)$ \\
\hline & $164-192^{\mathrm{d}}$ & 127.8 & $68.0(13.3)$ & $33.2(11.1)$ & $0.66(0.35)$ & $184.0(94.7)$ & $94.9(45.2)$ & $23.8(5.1)$ & $0.79(0.19)$ & $0.42(0.14)$ \\
\hline & 193-230 & 219.6 & 77.7 (11.9) & $13.8(6.7)$ & $0.19(0.13)$ & 50.4 (29.9) & $51.5(16.4)$ & $27.8(8.6)$ & $1.01(0.24)$ & $0.70(0.12)$ \\
\hline & $231-300^{\mathrm{d}}$ & 43 & $51.9(12.7)$ & 31.7 (11.6) & $0.94(0.52)$ & $178.5(68.8)$ & $77.4(27.5)$ & $25.6(6.8)$ & $0.69(0.23)$ & $0.36(0.14)$ \\
\hline \multirow{3}{*}{2007} & $100-143^{\mathrm{d}}$ & 61.8 & $35.2(6.4)$ & $57.8(8.3)$ & $2.37(0.66)$ & $426.9(148.8)$ & $96.1(29.4)$ & $18.1(5.4)$ & $0.41(0.13)$ & $0.16(0.07)$ \\
\hline & $151-200^{\mathrm{d}}$ & 146.8 & $49.5(18.2)$ & $37.0(17.7)$ & $1.41(1.06)$ & $314.1(225.6)$ & $91.7(42.8)$ & $25.3(7.1)$ & $0.58(0.23)$ & $0.35(0.16)$ \\
\hline & $200-300$ & 396.8 & $66.0(16.3)$ & $15.5(8.5)$ & $0.35(0.32)$ & $74.1(27.3)$ & $61.1(22.7)$ & $30.4(9.2)$ & $0.87(0.20)$ & $0.60(0.15)$ \\
\hline \multirow{7}{*}{2008} & $100-117$ & 53.4 & $16.3(14.1)$ & $71.8(9.7)$ & $1.86(1.12)$ & $206.9(102.0)$ & $60.7(22.9)$ & $13.6(4.1)$ & $0.59(0.35)$ & $0.21(0.14)$ \\
\hline & $118-155^{\mathrm{d}}$ & 15.6 & $58.8(12.3)$ & $39.5(10.7)$ & $0.71(0.36)$ & $130.8(48.6)$ & $81.1(32.3)$ & $14.7(4.2)$ & $0.81(0.23)$ & $0.31(0.11)$ \\
\hline & $156-188$ & 212.7 & $68.1(14.6)$ & $33.3(10.7)$ & $0.35(0.23)$ & $70.2(33.4)$ & $56.1(20.6)$ & $19.3(5.9)$ & $0.94(0.23)$ & $0.53(0.14)$ \\
\hline & $189-212^{\mathrm{d}}$ & 26 & $73.5(12.7)$ & $20.4(7.5)$ & $0.18(0.15)$ & $59.3(27.1)$ & $67.4(41.1)$ & $27.8(6.8)$ & $1.07(0.25)$ & $0.68(0.11)$ \\
\hline & 213-239 & 173.4 & $74.8(11.9)$ & $11.8(6.2)$ & $0.24(0.16)$ & $61.5(23.7)$ & $55.8(14.3)$ & $19.3(5.2)$ & $0.92(0.14)$ & $0.57(0.10)$ \\
\hline & $240-251^{\mathrm{d}}$ & 19.2 & $60.4(12.6)$ & $23.4(9.9)$ & $0.42(0.22)$ & 88.7 (34.6) & $60.4(15.3)$ & $18.0(4.1)$ & $0.87(0.21)$ & $0.46(0.10)$ \\
\hline & $252-300$ & 116.2 & $47.2(5.7)$ & $39.2(3.6)$ & $0.41(0.22)$ & $72.1(17.8)$ & $57.3(28.9)$ & $18.4(4.4)$ & $0.85(0.23)$ & $0.48(0.10)$ \\
\hline \multirow{3}{*}{2009} & $100-158^{\mathrm{d}}$ & $37.6+52$ & $36.0(16.5)$ & $48.8(13.4)$ & $1.90(0.83)$ & $298.9(150.8)$ & $84.2(39.3)$ & $18.2(3.8)$ & $0.43(0.19)$ & $0.21(0.08)$ \\
\hline & $165-186^{\mathrm{d}}$ & 1.2 & $47.8(15.6)$ & $38.1(14.8)$ & $1.32(0.78)$ & $360.5(139.8)$ & $137.4(43.8)$ & $21.2(5.9)$ & $0.53(0.28)$ & $0.24(0.10)$ \\
\hline & $187-235$ & $265+32$ & $65.9(12.8)$ & $12.4(6.7)$ & $0.28(0.18)$ & $61.2(30.9)$ & $53.0(22.8)$ & $27.4(6.6)$ & $0.82(0.18)$ & $0.66(0.13)$ \\
\hline & $236-300^{\mathrm{d}}$ & $20.4+20$ & $50.4(20.5)$ & $33.1(18.4)$ & $1.28(1.31)$ & $208.3(194.3)$ & $72.3(26.5)$ & $26.9(10.7)$ & $0.64(0.28)$ & $0.39(0.21)$ \\
\hline 2006 & growing season & $466+86$ & $59.1(18.9)$ & $31.8(16.4)$ & $1.60(3.94)$ & $231.4(338.3)$ & 77.9 (33.6) & $24.0(7.4)$ & $0.76(0.30)$ & $0.41(0.21)$ \\
\hline 2007 & growing season & 630 & $56.6(19.5)$ & $28.7(19.6)$ & $0.93(0.98)$ & $192.2(190.7)$ & $75.4(34.0)$ & $26.9(9.3)$ & $0.73(0.44)$ & $0.46(0.22)$ \\
\hline 2008 & growing season & 630 & $66.1(15.2)$ & $22.1(13.4)$ & $0.73(1.04)$ & $118.1(115.3)$ & $68.3(44.9)$ & $18.5(6.3)$ & $0.89(0.59)$ & $0.43(0.19)$ \\
\hline 2009 & growing season & $400+195$ & 48.5 (21.9) & $34.6(18.5)$ & $1.54(2.19)$ & $248.9(273.3)$ & $77.1(39.1)$ & $23.8(8.5)$ & $0.63(0.38)$ & $0.39(0.24)$ \\
\hline $\begin{array}{l}\text { Dry years } \\
(2006,2009)\end{array}$ & growing season & - & $52.6(22.3)$ & $33.0(18.4)$ & $1.57(3.17)$ & $240.3(306.9)$ & $77.5(36.5)$ & $23.9(8.0)$ & $0.68(0.31)$ & $0.40(0.22)$ \\
\hline $\begin{array}{l}\text { Wet years } \\
(2007,2008)\end{array}$ & growing season & - & $61.5(18.1)$ & $25.1(17.0)$ & $0.83(1.01)$ & $153.1(159.7)$ & $71.6(40.3)$ & $22.5(8.9)$ & $0.81(0.29)$ & $0.45(0.20)$ \\
\hline
\end{tabular}

a deciduous broadleaved forest in the southern United States (Wilson and Baldocchi, 2000). Seasonal drought stress had a discernible impact on the Bowen ratio of this poplar plantation. However, compared to the reported $\beta$ values such as
0.74 in a temperate mixed forest (Wu et al., 2007), 0.81 in a boreal Scots pine forest (Launiainen, 2010), and 0.89 in a loblolly pine plantation (Sun et al., 2010), the average $\beta$ values in wet years were close to the above values. $\beta$ was higher 
in seasonal drought periods and dry years than most temperate coniferous forests (Mean $=1.07$, Wilson et al., 2002b), which typically had higher $\beta$ values. The high $\beta$ value in this study reflects the semiarid conditions, and suggests a low tree water supply which might be resulted from the combination of low rainfall, the sandy soil's low water-holding capacity and the high plant and atmospheric water demand. It has been suggested that the large-scale establishment of poplar plantations in sandy semiarid regions of northern China could have an adverse impact on the region's groundwater reserves ( $\mathrm{Li}$ et al., 2014; Petzold et al., 2011). Our findings corroborate the hypothesis that drought would trigger significant changes in the energy partitioning of water-demanding poplar species in a water-stressed region.

\subsection{Biophysical control on Bowen ratio}

The Bowen ratio is dependent on the interactions of climatic and biological factors (Perez et al., 2008; Wilson and Baldocchi, 2000). $R_{i}$ quantifies the climatic control on energy partitioning and tends to decrease the Bowen ratio. A higher $R_{i}$ implies a warm and dry climate in continental regions (Raupach, 2000; Wilson et al., 2002b). $R_{\mathrm{S}}$ reflects the physiological control on surface energy exchange of an ecosystem (Costa et al., 2010; Launiainen, 2010; Zhou et al., 2010) and generally increases the Bowen ratio.

In this study, $R_{\mathrm{S}}$ similarly varied seasonally with plant phenology and showed similar seasonal characteristics to other deciduous forests during the course of the growing season (Cabral et al., 2010; Kutsch et al., 2008; Li et al., 2012). As reported by Tchebakova et al. (2002), $R_{\mathrm{S}}$ in seasonal droughtstressed periods was much higher than in non-stressed periods. It has been shown that drought stress during the canopy development affects leaf area and may have lasting effects on canopy gas exchange through the entire growing season, even after the moisture limitation is removed (Noormets et al., 2008), which may explain significant differences in $R_{\mathrm{S}}$ between the wet years of 2007 and 2008 (Fig. 9). Compared with the $R_{\mathrm{S}}$ in other studies, the $R_{\mathrm{S}}: \mathrm{LAI}$ in dry years in the current study was close to that of the Euphrates Poplar (Populus euphratica Oliv.; $130.2 \mathrm{~s} \mathrm{~m}^{-1} \mathrm{LAI}^{-1}$ ) and smaller than that of the Gansu Poplar (Populus gansuensis Wang et Yang; $189.4 \mathrm{~s} \mathrm{~m}^{-1} \mathrm{LAI}^{-1}$ ) in semiarid regions (Chen et al., 2004). In wet years it was similar to that of poplar $\left(58.6 \mathrm{~s} \mathrm{~m}^{-1}\right.$ $\mathrm{LAI}^{-1}$; Wilson et al., 2002b) and boreal aspen during the full-leaf period (51.8 $\mathrm{s} \mathrm{m}^{-1} \mathrm{LAI}^{-1}$; Blanken et al., 1997) in mesic temperate regions. $R_{\mathrm{S}}$ is primarily driven by solar radiation, moisture availability, and VPD (Fernández et al., 2009; Li et al., 2012), and modulated by leaf area and stomatal resistance, which in turn changes as a function of the above factors (Wilson and Baldocchi, 2000). Compared to the strong correlation between $R_{\mathrm{S}}$ and LAI in wet years, the increased scatter in the $R_{\mathrm{S}}$-LAI relationship during dry years (Fig. 6) suggests that $R_{\mathrm{s}}$ in dry years was also influenced by other physiological and non-physiological (e.g., soil evapo-

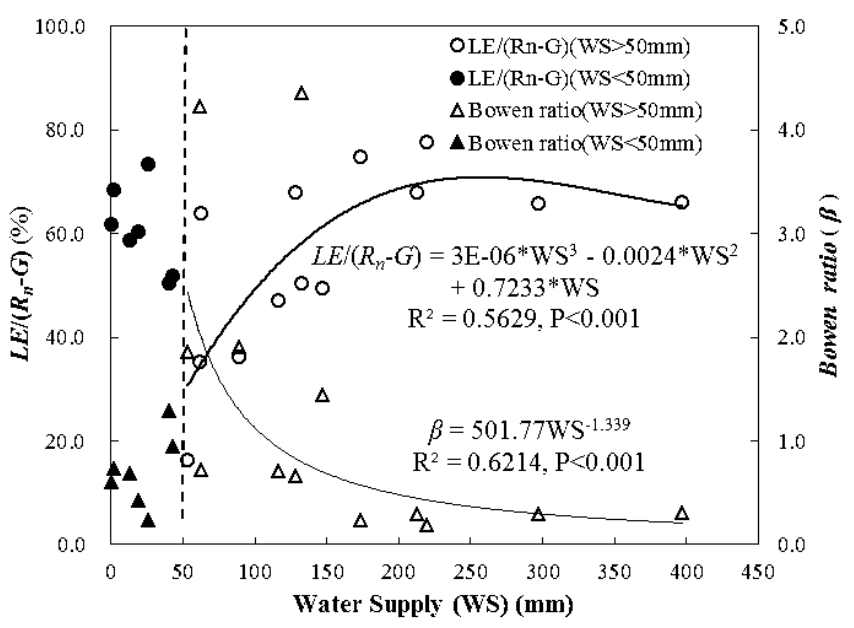

Figure 8. The response of Bowen ratio and LE/ $\left(R_{\mathrm{n}}-G\right)$ to water supply (WS; including precipitation $(P)$ and irrigation $(I)$ during each individual period) of the different periods across the four growing seasons.

ration, canopy structure, and turbulence) factors (Wilson et al., 2002b). The mean $R_{i}$ in the current study was higher than the mean $R_{i}$ reported for temperate forests in Wilson et al. (2002b; $t=5.91, \mathrm{~d} f=741, p<0.001$ ), but was $\sim 50 \%$ lower than the value reported by $\mathrm{Li}$ et al. (2009) in a vineyard in Gansu province in China $(t=-29.87, \mathrm{~d} f=741$, $p<0.001)$, as might be expected given the predominant climatic conditions.

On the seasonal scale, the Bowen ratio and $R_{\mathrm{S}}$ of this poplar plantation were correlated and consistent with Wilson et al. (2002b) and Li et al. (2009), but differed in wet and dry years (Fig. 10). The water limitation during the dry years manifested in disproportional increase in $R_{\mathrm{s}}$ than the Bowen ratio; this response may serve as an indicator as to when water reserves are being depleted. At the extremes, the relationship converges, but as water becomes limiting, stomatal closure and increased $R_{\mathrm{S}}$ do not appear to be able to affect the seasonal dynamics of the Bowen ratio. The partial correlation analysis indicated that $R_{\mathrm{s}}$ and $R_{i}$ had strong positive and negative effects, respectively, on $\beta$ in both wet and dry years (Table 4 ), which could not be detected through correlation analysis (e.g., the impact of $R_{i}$ and $R_{\mathrm{a}}$ on $\beta$ ). Furthermore, the regulation of the Bowen ratio by $R_{\mathrm{S}}$ and $R_{i}$ seemed stronger in dry than in wet years. $R_{\mathrm{a}}$ had a significant negative impact on the Bowen ratio in wet years, but not in dry years.

The average $\mathrm{LE} / \mathrm{LE}_{\mathrm{eq}}$ in the growing season was 0.74 at our site, which is similar to deciduous forests $(0.72$; Wilson et al., 2002b), but smaller than at a temperate broadleaved forest (0.82; Komatsu, 2005). The average $\Omega$ value of $0.42 \pm 0.22(0.39-0.46)$ was close to the other forests $(0.26-$ 0.4, Wilson and Baldocchi (2000); 0.25-0.43, Motzer et al. (2005)). As essentially implied by the Penman-Monteith 


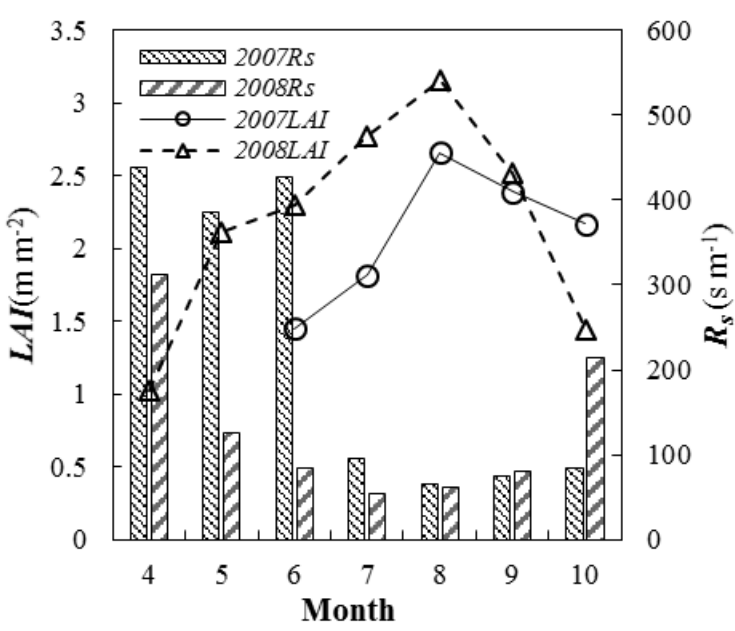

Figure 9. Seasonal variations of monthly average LAI and $R_{\mathrm{S}}$ during the growing seasons in the wet years of 2007 and 2008.

Table 4. The correlation analysis between the Bowen ratio $(\beta)$ and $R_{\mathrm{S}}, R_{i}$, and $R_{\mathrm{a}}$.

\begin{tabular}{lrrrrrrr}
\hline & & \multicolumn{3}{c}{ Partial correlation analysis* } & \multicolumn{3}{c}{ Correlation analysis } \\
\cline { 2 - 8 } & \multicolumn{1}{c}{ SOCC } & $p$ & $\mathrm{~d} f$ & Pearson & $p$ & $\mathrm{~d} f$ \\
\hline \multirow{3}{*}{ Dry year } & $\beta \& R_{\mathrm{S}}$ & 0.965 & $<0.001$ & & 0.939 & $<0.001$ & \\
& $\beta \& R_{i}$ & -0.667 & $<0.001$ & 347 & -0.042 & $=0.436$ & 349 \\
& $\beta \& R_{\mathrm{a}}$ & 0.037 & $=0.496$ & & -0.221 & $<0.001$ & \\
\hline \multirow{3}{*}{ Wet year } & $\beta \& R_{\mathrm{S}}$ & 0.905 & $<0.001$ & & 0.85 & $<0.001$ & \\
& $\beta \& R_{i}$ & -0.614 & $<0.001$ & 383 & 0.64 & $=0.006$ & 385 \\
& $\beta \& R_{\mathrm{a}}$ & -0.217 & $<0.001$ & & -0.286 & $<0.001$ & \\
\hline * Partial correlation analysis was carried out between the Bowen ratio and each of the three resistance \\
parameters $\left(R_{\mathrm{S}}, R_{i}\right.$, and $R_{\mathrm{a}}$ ) with the other two as controlling variables. SOCC is the abbreviation of \\
"second-order correlation coefficient".
\end{tabular}

equation, $\mathrm{LE} / \mathrm{LE}_{\mathrm{eq}}$ exponentially related to $R_{\mathrm{S}}$ during the growing season (Fig. 7), which is equivalent to the logarithmic relationship between $\mathrm{LE} / \mathrm{LE}_{\mathrm{eq}}$ and $G_{\mathrm{s}}$ (surface conductance) reported by other studies (Chen et al., 2009; Hossen et al., 2011; Zhu et al., 2014). The asymptotic value of $\mathrm{LE} / \mathrm{LE}_{\mathrm{eq}}$ in dry years $(0.89)$ and wet years $(0.96)$ were both lower than the 1.1-1.4 range typical in temperate deciduous forest reported by Monteith (1995), indicating that our study site was drier than these reference sites during both dry and wet years. The low $\mathrm{LE} / \mathrm{LE}_{\mathrm{eq}}$ values under dry surface conditions of the ecosystem in this study may also be related to the high porosity of the sandy soil and the low ground water table (Zhao et al., 2013). Overall, as indicated by the lower $\Omega$ values and the significant correlation coefficients between $\mathrm{LE} / \mathrm{LE}_{\mathrm{eq}}$ and $R_{\mathrm{s}}, R_{\mathrm{S}}$ was the major factor controlling the LE during the growing season, which was consistent with the relations between $R_{\mathrm{S}}$ and the Bowen ratio. In addition, LE was more coupled to the atmosphere during the dry years and seasonal drought periods across the growing seasons, as reported in other studies (Bagayoko et al., 2007; Bracho et al., 2008; Zha et al., 2013).

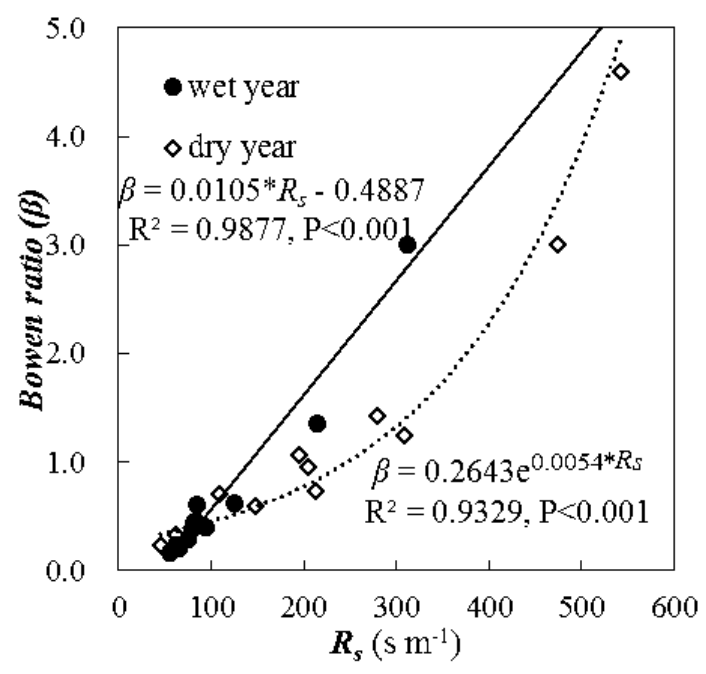

Figure 10. Response of monthly average Bowen ratio $(\beta)$ on surface resistance $\left(R_{\mathrm{S}}\right)$ in the wet and dry years.

\subsection{Implications for poplar plantation establishments}

As forestry is a long-term endeavor, with the economic payback decades from stand establishment, the availability of resources for the stand to prosper should come naturally to natural resource managers. Supplementing limited resources directly (fertilization, irrigation) or indirectly (competition control, site preparation, thinning) is commonplace in commercial forestry, but it has to be sustainable in the broader context of the region's ecosystems and livelihoods. As we show in a forthcoming study, the water needs of poplar plantation exceed the annual precipitation in the region, and plant survival during dry years depends on irrigation from groundwater. In the current study, energy partitioning to latent and sensible heat and surface resistance was sensitive to climatological drought - even under irrigation - as indicated by low $\mathrm{LE} / \mathrm{LE}_{\mathrm{eq}}(<1)$ and low values of the decoupling coefficient ( $\Omega$; Zhu et al., 2014); the dry surface conditions dominated the poplar plantation in both wet and dry years. In wet years, the plantation itself is in hydrologic balance with the water that arrives as precipitation, with evapotranspiration consuming nearly all of the precipitation. The same is true in dry years, but irrigation increases ET even further by depleting groundwater. Even if the plantations were in hydrologic balance with water delivered as precipitation, their existence and operation could be a threat to adjacent ecosystems and livelihoods if those rely on runoff or groundwater recharge from the areas where the plantation has been sited. In the absence of the plantations it is likely that groundwater recharge would increase, especially given the sandy textured soil that tends to allow rapid infiltration and percolation as well as limit moisture delivery to the atmosphere directly from the soil surface itself. While poplar plantation growth in this water-limited location might be sustained by the modest precipitation in the 
region, it could still be unsustainable for the broader context of the region's ecosystems and livelihoods. However, further study to truly access these effects is needed by comparing the surface water balance and/or spatial and temporal variations of groundwater levels at an adjacent, similar site without a plantation.

\section{Conclusions}

The seasonal drought stress affected the dynamics of individual turbulent energy fluxes and the surface resistances in the poplar plantation during the growing seasons. Partitioning of available energy into latent (LE) and sensible heat $(H)$ flux responded to meteorological drought and resulted in higher $\beta$ in dry years (1.57) than in wet years (0.83). Similar to the response of the Bowen ratio on drought conditions, the LAI normalized surface resistance $\left(R_{\mathrm{S}}: \mathrm{LAI}\right)$ was $33 \%$ higher in dry than in wet years. Correspondingly, the contrasting effects of $R_{\mathrm{S}}$ and $R_{i}$ on the Bowen ratio were stronger in dry years than in wet years, while the effect of $R_{\mathrm{a}}$ was stronger in wet years. $R_{\mathrm{S}}$ was the major factor in controlling energy partitioning during the growing season, as indicated by the relatively low decoupling coefficient $(\Omega)$ values. Furthermore, the low $\mathrm{LE} / \mathrm{LE}_{\mathrm{eq}}(<1)$ of poplar plantations was an indication of the permanent limitation of plant water use and surface energy partitioning by water availability. Even at mean long-term precipitation, the water demands of poplar plantations may consume nearly all of it and leave little for run-off and groundwater recharge in this semiarid region, potentially compromising the region's ecosystems and livelihoods.

Acknowledgements. This study was financially supported by the National Special Research Program for Forestry, entitled "Forest Management Affecting the Coupling of Ecosystem Carbon and Water Exchange with Atmosphere" (grant no. 201204102). The first author also thanks the financial support of the Beijing Municipality Educational Committee under the graduate student training program. Partial support by the US-China Carbon Consortium (USCCC) is acknowledged as well. Authors thank Dr. Christopher A. Williams (Associate Editor) and anonymous reviewers for their insightful comments which helped to improve our original manuscript greatly.

Edited by: C. A. Williams

\section{References}

Admiral, S. W., Lafleur, P. M., and Roulet, N. T.: Controls on latent heat flux and energy partitioning at a peat bog in eastern Canada, Agr. Forest Meteorol., 140, 308-321, 2006.

Arain, M. A., Black, T. A., Barr, A. G., Griffis, T. J., Morgenstern, K., and Nesic, Z.: Year-round observations of the energy and water vapour fluxes above a boreal black spruce forest, Hydrol. Process., 17, 3581-3600, 2003.
Bagayoko, F., Yonkeu, S., Elbers, J., and de Giesen, N. V.: Energy partitioning over the west African savanna: Multi-year evaporation and surface conductance measurements in Eastern Burkina Faso, J. Hydrol., 334, 545-559, 2007.

Baldocchi, D., Kelliher, F. M., Black, T. A., and Jarvis, P.: Climate and vegetation controls on boreal zone energy exchange, Glob. Change Biol., 6, 69-83, 2000.

Blanken, P. D., Black, T. A., Yang, P. C., Neumann, H. H., Nesic, Z., Staebler, R., den Hartog, G., Novak, M. D., and Lee, X.: Energy balance and canopy conductance of a boreal aspen forest: Partitioning overstory and understory components, J. Geophys. Res.-Atmos., 102, 28915-28927, 1997.

Bracho, R., Powell, T. L., Dore, S., Li, J. H., Hinkle, C. R., and Drake, B. G.: Environmental and biological controls on water and energy exchange in Florida scrub oak and pine flatwoods ecosystems, J. Geophys. Res.-Biogeo., 113, G02004, doi:10.1029/2007JG000469, 2008.

Burba, G. G., McDermitt, D. K., Grelle, A., Anderson, D. J., and $\mathrm{Xu}, \mathrm{L} .:$ Addressing the influence of instrument surface heat exchange on the measurements of $\mathrm{CO}_{2}$ flux from open-path gas analyzers, Glob. Change Biol., 14, 1854-1876, 2008.

Cabral, O. M. R., Rocha, H. R., Gash, J. H. C., Ligo, M. A. V., Freitas, H. C., and Tatsch, J. D.: The energy and water balance of a Eucalyptus plantation in southeast Brazil, J. Hydrol., 388, 208-216, 2010.

Chen, R., Kang, E., Zhang, Z., Zhao, W., Song, K., Zhang, J., and Lan, Y.: Estimation of tree transpiration and response of tree conductance to meteorological variables in desert-oasis system of Northwest China, Sci. China Ser. D, 47, 9-20, 2004.

Chen, S. P., Chen, J. Q., Lin, G. H., Zhang, W. L., Miao, H. X., Wei, L., Huang, J. H., and Han, X. G.: Energy balance and partition in Inner Mongolia steppe ecosystems with different land use types, Agr. Forest Meteorol., 149, 1800-1809, 2009.

Cho, J., Oki, T., Yeh, P. J. F., Kim, W., Kanae, S., and Otsuki, K.: On the relationship between the Bowen ratio and the near-surface air temperature, Theor. Appl. Climatol., 108, 135-145, 2012.

Costa, M. H., Biajoli, M. C., Sanches, L., Malhado, A. C. M., Hutyra, L. R., da Rocha, H. R., Aguiar, R. G., and de Araujo, A. C.: Atmospheric versus vegetation controls of Amazonian tropical rain forest evapotranspiration: Are the wet and seasonally dry rain forests any different?, J. Geophys. Res.-Biogeo., 115, G04021, doi:10.1029/2009JG001179, 2010.

Ding, Y. H., Ren, G. Y., Zhao, Z. C., Xu, Y., Luo, Y., Li, Q. P., and Zhang, J.: Detection, causes and projection of climate change over China: An overview of recent progress, Adv. Atmos. Sci., 24, 954-971, 2007.

Dou, J. X., Zhang, Y. P., Yu, G. R., Zhao, S. J., Wang, X., and Song, Q. H.: A preliminary study on the heat storage fluxes of a tropical seasonal rain forest in Xishuangbanna, Sci. China Ser. D, 49, 163-173, 2006.

Falge, E., Baldocchi, D., Olson, R., Anthoni, P., Aubinet, M., Bernhofer, C., Burba, G., Ceulemans, R., Clement, R., Dolman, H., Granier, A., Gross, P., Grünwald, T., Hollinger, D., Jensen, N.O., Katul, G., Keronen, P., Kowalski, A., Lai, C. T., Law, B. E., Meyers, T., Moncrieff, J., Moors, E., Munger, J. W., Pilegaard, K., Rannik, Ü., Rebmann, C., Suyker, A., Tenhunen, J., Tu, K., Verma, S., Vesala, T., Wilson, K., and Wofsy, S.: Gap filling strategies for defensible annual sums of net ecosystem exchange, Agr. Forest Meteorol., 107, 43-69, 2001. 
Fang, S.: Silviculture of poplar plantation in China: A review, Yingyong Shengtai Xuebao, 19, 2308-2316, 2008.

Fernández, M. E., Gyenge, J., and Schlichter, T.: Water flux and canopy conductance of natural versus planted forests in Patagonia, South America, Trees, 23, 415-427, 2009.

Foken, T. and Wichura, B.: Tools for quality assessment of surfacebased flux measurements, Agr. Forest Meteorol., 78, 83-105, 1996.

Gao, Y., Zhu, X., Yu, G., He, N., Wang, Q., and Tian, J.: Water use efficiency threshold for terrestrial ecosystem carbon sequestration in China under afforestation, Agr. Forest Meteorol., 195196, 32-37, 2014.

Gielen, B. and Ceulemans, R.: The likely impact of rising atmospheric $\mathrm{CO} 2$ on natural and managed Populus: a literature review, Environ. Pollut., 115, 335-358, 2001.

Goldstein, A. H., Hultman, N. E., Fracheboud, J. M., Bauer, M. R., Panek, J. A., Xu, M., Qi, Y., Guenther, A. B., and Baugh, W.: Effects of climate variability on the carbon dioxide, water, and sensible heat fluxes above a ponderosa pine plantation in the Sierra Nevada (CA), Agr. Forest Meteorol., 101, 113-129, 2000.

Goulden, M. L., Munger, J. W., Fan, S.-M., Daube, B. C., and Wofsy, S. C.: Measurements of carbon sequestration by longterm eddy covariance: methods and a critical evaluation of accuracy, Glob. Change Biol., 2, 169-182, 1996.

Granier, A., Reichstein, M., Breda, N., Janssens, I. A., Falge, E., Ciais, P., Grunwald, T., Aubinet, M., Berbigier, P., Bernhofer, C., Buchmann, N., Facini, O., Grassi, G., Heinesch, B., Ilvesniemi, H., Keronen, P., Knohl, A., Kostner, B., Lagergren, F., Lindroth, A., Longdoz, B., Loustau, D., Mateus, J., Montagnani, L., Nys, C., Moors, E., Papale, D., Peiffer, M., Pilegaard, K., Pita, G., Pumpanen, J., Rambal, S., Rebmann, C., Rodrigues, A., Seufert, G., Tenhunen, J., Vesala, I., and Wang, Q.: Evidence for soil water control on carbon and water dynamics in European forests during the extremely dry year: 2003, Agr. Forest Meteorol., 143, 123-145, 2007.

Grünwald, T. and Bernhofer, C.: A decade of carbon, water and energy flux measurements of an old spruce forest at the Anchor Station Tharandt, Tellus B, 59, 387-396, 2007.

Guo, H. Q., Zhao, B., Chen, J. Q., Yan, Y. E., Li, B., and Chen, J. K.: Seasonal Changes of Energy Fluxes in an Estuarine Wetland of Shanghai, China, Chinese Geogr. Sci., 20, 23-29, 2010.

Guo, L., Li, Q., Yan, C., Mei, X., and Li, Y.: Effects of small area irrigation on water and heat transport of winter wheat field under drought condition[J], Transactions of the Chinese Society of Agricultural Engineering, 24, 20-24, 2008.

Hernandez-Ramirez, G., Hatfield, J. L., Prueger, J. H., and Sauer, T. J.: Energy balance and turbulent flux partitioning in a cornsoybean rotation in the Midwestern US, Theor. Appl. Climatol., 100, 79-92, 2010.

Holwerda, F., Bruijnzeel, L. A., Scatena, F. N., Vugts, H. F., and Meesters, A. G. C. A.: Wet canopy evaporation from a Puerto Rican lower montane rain forest: The importance of realistically estimated aerodynamic conductance, J. Hydrol., 414, 1-15, 2012.

Hossen, M. S., Mano, M., Miyata, A., Baten, M. A., and Hiyama, T.: Surface energy partitioning and evapotranspiration over a double-cropping paddy field in Bangladesh, Hydrol. Process., 26, 1311-1320, doi:10.1002/hyp.8232, 2011.

Humphreys, E. R., Black, T. A., Ethier, G. J., Drewitt, G. B., Spittlehouse, D. L., Jork, E. M., Nesic, Z., and Livingston, N. J.: Annual and seasonal variability of sensible and latent heat fluxes above a coastal Douglas-fir forest, British Columbia, Canada, Agr. Forest Meteorol., 115, 109-125, 2003.

Jamiyansharav, K., Ojima, D., Pielke, R. A., Parton, W., Morgan, J., Beltrán-Przekurat, A., LeCain, D., and Smith, D.: Seasonal and interannual variability in surface energy partitioning and vegetation cover with grazing at shortgrass steppe, J. Arid. Environ., 75, 360-370, 2011.

Jarvis, P. G. and McNaughton, K. G.: Stomatal Control of Transpiration: Scaling Up from Leaf to Region, in: Advances in Ecological Research, edited by: MacFadyen, A. and Ford, E. D., Academic Press, London NW1 7BY, UK, 1-49, 1986.

Kim, H.-S., Oren, R., and Hinckley, T. M.: Actual and potential transpiration and carbon assimilation in an irrigated poplar plantation, Tree Physiol., 28, 559-577, 2008.

Komatsu, H.: Forest categorization according to dry-canopy evaporation rates in the growing season: comparison of the PriestleyTaylor coefficient values from various observation sites, Hydrol. Process., 19, 3873-3896, 2005.

Kumagai, T. o., Saitoh, T. M., Sato, Y., Morooka, T., Manfroi, O. J., Kuraji, K., and Suzuki, M.: Transpiration, canopy conductance and the decoupling coefficient of a lowland mixed dipterocarp forest in Sarawak, Borneo: dry spell effects, J. Hydrol., 287, 237251, 2004.

Kutsch, W. L., Hanan, N., Scholes, B., McHugh, I., Kubheka, W., Eckhardt, H., and Williams, C.: Response of carbon fluxes to water relations in a savanna ecosystem in South Africa, Biogeosciences, 5, 1797-1808, doi:10.5194/bg-5-1797-2008, 2008.

Launiainen, S.: Seasonal and inter-annual variability of energy exchange above a boreal Scots pine forest, Biogeosciences, 7, 3921-3940, doi:10.5194/bg-7-3921-2010, 2010.

Li, S., Tong, L., Li, F. S., Zhang, L., Zhang, B. Z., and Kang, S. Z.: Variability in energy partitioning and resistance parameters for a vineyard in northwest China, Agr. Water Manage., 96, 955-962, 2009.

Li, Y. Z., Qin, H. Y., Xie, Y. H., Wang, W., Chen, X. S., and Zhang, C. M.: Physiological mechanism for the reduction in soil water in poplar (Populus deltoides) plantations in Dongting Lake wetlands, Wetl. Ecol. Manag., 22, 25-33, 2014.

Li, Z., Yu, G., Wen, X., Zhang, L., Ren, C., and Fu, Y.: Energy balance closure at ChinaFLUX sites, Sci. China Ser. D, 48, 12, 51-62, 2005.

Li, Z., Niu, L., Yuan, F., Guan, D., Wang, A., Jin, C., and Wu, J.: Canopy conductance characteristics of poplar in agroforestry system in west Liaoning Province of Northeast China, Chinese Journal of Applied Ecology, 23, 2975-2982, 2012.

Mahrt, L.: Stratified Atmospheric Boundary Layers, Bound.-Lay. Meteorol., 90, 375-396, 1999.

Martín-García, J., Jactel, H., and Diez, J. J.: Patterns and monitoring of Sesia apiformis infestations in poplar plantations at different spatial scales, J. Appl. Entomol., 135, 382-392, 2011.

Migliavacca, M., Meroni, M., Manca, G., Matteucci, G., Montagnani, L., Grassi, G., Zenone, T., Teobaldelli, M., Goded, I., Colombo, R., and Seufert, G.: Seasonal and interannual patterns of carbon and water fluxes of a poplar plantation under peculiar eco-climatic conditions, Agr. Forest Meteorol., 149, 1460-1476, 2009.

Monteith, J.: A reinterpretation of stomatal responses to humidity, Plant Cell Environ., 18, 357-364, 1995. 
Motzer, T., Munz, N., Küppers, M., Schmitt, D., and Anhuf, D.: Stomatal conductance, transpiration and sap flow of tropical montane rain forest trees in the southern Ecuadorian Andes, Tree Physiol., 25, 1283-1293, 2005.

Nakai, T., Van Der Molen, M., Gash, J., and Kodama, Y.: Correction of sonic anemometer angle of attack errors, Agr. Forest Meteorol., 136, 19-30, 2006.

Noormets, A., McNulty, S. G., DeForest, J. L., Sun, G., Li, Q., and Chen, J.: Drought during canopy development has lasting effect on annual carbon balance in a deciduous temperate forest, New Phytol., 179, 818-828, 2008.

Noormets, A., Zhou, R., Chen, J., and Billesbach, D.: EC_Processor page http://www4.ncsu.edu/ anoorme/ECP/index.html (last access: 20 September 2014), 2010.

Ozdogan, M., Rodell, M., Beaudoing, H. K., and Toll, D. L.: Simulating the Effects of Irrigation over the United States in a Land Surface Model Based on Satellite-Derived Agricultural Data, J. Hydrometeorol., 11, 171-184, 2010.

Paw U, K. T., Baldocchi, D. D., Meyers, T. P., and Wilson, K. B.: Correction Of Eddy-Covariance Measurements Incorporating Both Advective Effects And Density Fluxes, Bound.-Lay. Meteorol., 97, 487-511, 2000.

Pereira, A. R.: The Priestley-Taylor parameter and the decoupling factor for estimating reference evapotranspiration, Agr. Forest Meteorol., 125, 305-313, 2004.

Perez, P. J., Castellvi, F., and Martínez-Cob, A.: A simple model for estimating the Bowen ratio from climatic factors for determining latent and sensible heat flux, Agr. Forest Meteorol., 148, 25-37, 2008.

Petzold, R., Schwarzel, K., and Feger, K. H.: Transpiration of a hybrid poplar plantation in Saxony (Germany) in response to climate and soil conditions, Eur. J. Forest Res., 130, 695-706, 2011.

Qiu, G., Yin, J., and Geng, S.: Impact of Climate and Land-Use Changes on Water Security for Agriculture in Northern China, Journal of Integrative Agriculture, 11, 144-150, 2012.

Raupach, M.: Equilibrium evaporation and the convective boundary layer, Bound.-Lay. Meteorol., 96, 107-142, 2000.

Schmid, H. P., Su, H. B., Vogel, C. S., and Curtis, P. S.: Ecosystematmosphere exchange of carbon dioxide over a mixed hardwood forest in northern lower Michigan, J. Geophys. Res.-Atmos., 108, 19 pp., 4417, doi:10.1029/2002JD003011, 2003.

Standardization Administration, P. R. China: Classification of meteorological drought, in: National Standard of People's Republic of China GB/T 20481-2006, China Standard Press, Beijing, 1-16, 2006.

Stanturf, J. A. and Oosten, C. v.: Operational Poplar and Willow Culture. In: Poplars and willows: trees for society and the environment, edited by: Isebrands, J. G. and Richardson, J., The Food and Agriculture Organization of the United Nations and CABI, available at: http://www.fao.org/forestry/ipc/69946@158687/en/ (last access: 03 April 2015), 2014.

Stoy, P. C., Mauder, M., Foken, T., Marcolla, B., Boegh, E., Ibrom, A., Arain, M. A., Arneth, A., Aurela, M., Bernhofer, C., Cescatti, A., Dellwik, E., Duce, P., Gianelle, D., van Gorsel, E., Kiely, G., Knohl, A., Margolis, H., McCaughey, H., Merbold, L., Montagnani, L., Papale, D., Reichstein, M., Saunders, M., Serrano-Ortiz, P., Sottocornola, M., Spano, D., Vaccari, F., and Varlagin, A.: A data-driven analysis of energy balance closure across FLUXNET research sites: The role of landscape scale heterogeneity, Agr. Forest Meteorol., 171-172, 137-152, 2013.

Sun, G., Noormets, A., Gavazzi, M., McNulty, S., Chen, J., Domec, J.-C., King, J., Amatya, D., and Skaggs, R.: Energy and water balance of two contrasting loblolly pine plantations on the lower coastal plain of North Carolina, USA, Forest Ecol. Manag., 259, 1299-1310, 2010.

Takagi, K., Kimura, R., and Şaylan, L.: Variability of surface characteristics and energy flux patterns of sunn hemp (Crotalaria juncea L.) under well-watered conditions, Theor. Appl. Climatol., 96, 261-273, 2009.

Tang, Y., Wen, X., Sun, X., and Wang, H.: Interannual Variation of the Bowen Ratio in a Subtropical Coniferous Plantation in Southeast China, 2003-2012, Plos One, 9, e88267, doi:10.1371/journal.pone.0088267, 2014.

Tchebakova, N. M., Kolle, O., Zolotoukhine, D., Arneth, A., Styles, J. M., Vygodskaya, N. N., Schluze, E.-D., Shibistova, O., and Lloyd, J.: Inter-annual and seasonal variations of energy and water vapour fluxes above a Pinus sylvestris forest in the Siberian middle taiga, Tellus B, 54, 537-551, 2002.

Wang, E., Yu, Q., Wu, D., and Xia, J.: Climate, agricultural production and hydrological balance in the North China Plain, Int. J. Climatol., 28, 1959-1970, 2008.

Webb, E. K., Pearman, G. I., and Leuning, R.: Correction of flux measurements for density effects due to heat and water vapour transfer, Q. J. Roy. Meteor. Soc., 106, 85-100, 1980.

Wilczak, J., Oncley, S., and Stage, S.: Sonic Anemometer Tilt Correction Algorithms, Bound.-Lay. Meteorol., 99, 127-150, 2001.

Wilske, B., Lu, N., Wei, L., Chen, S. P., Zha, T. G., Liu, C. F., Xu, W. T., Noormets, A., Huang, J. H., Wei, Y. F., Chen, J., Zhang, Z. Q., Ni, J., Sun, G., Guo, K., McNulty, S., John, R., Han, X. G., Lin, G. H., and Chen, J. Q.: Poplar plantation has the potential to alter the water balance in semiarid Inner Mongolia, J. Environ. Manage., 90, 2762-2770, 2009.

Wilson, K. B. and Baldocchi, D. D.: Seasonal and interannual variability of energy fluxes over a broadleaved temperate deciduous forest in North America, Agr. Forest Meteorol., 100, 1-18, 2000.

Wilson, K. B., Goldstein, A., Falge, E., Aubinet, M., Baldocchi, D., Berbigier, P., Bernhofer, C., Ceulemans, R., Dolman, H., Field, C., Grelle, A., Ibrom, A., Law, B. E., Kowalski, A., Meyers, T., Moncrieff, J., Monson, R., Oechel, W., Tenhunen, J., Valentini, R., and Verma, S.: Energy balance closure at FLUXNET sites, Agr. Forest Meteorol., 113, 223-243, 2002a.

Wilson, K. B., Baldocchi, D. D., Aubinet, M., Berbigier, P., Bernhofer, C., Dolman, H., Falge, E., Field, C., Goldstein, A., Granier, A., Grelle, A., Halldor, T., Hollinger, D., Katul, G., Law, B. E., Lindroth, A., Meyers, T., Moncrieff, J., Monson, R., Oechel, W., Tenhunen, J., Valentini, R., Verma, S., Vesala, T., and Wofsy, S.: Energy partitioning between latent and sensible heat flux during the warm season at FLUXNET sites, Water Resour. Res., 38, 301-30-11, 1294, doi:10.1029/2001WR000989, 2002 b.

Wu, J. B., Guan, D. X., Han, S. J., Shi, T. L., Jin, C. J., Pell, T. F., and Yu, G. R.: Energy budget above a temperate mixed forest in northeastern China, Hydrol. Process., 21, 2425-2434, 2007.

Zha, T. S., Li, C. Y., Kellomaki, S., Peltola, H., Wang, K. Y., and Zhang, Y. Q.: Controls of Evapotranspiration and $\mathrm{CO}_{2}$ Fluxes from Scots Pine by Surface Conductance and Abiotic Factors, Plos One, 8, e69027, doi:10.1371/journal.pone.0069027, 2013. 
Zhang, J. B., Shangguan, T., and Meng, Z. Q.: Changes in soil carbon flux and carbon stock over a rotation of poplar plantations in northwest China, Ecol. Res., 26, 153-161, 2011.

Zhang, Y., Kadota, T., Ohata, T., and Oyunbaatar, D.: Environmental controls on evapotranspiration from sparse grassland in Mongolia, Hydrol. Process., 21, 2016-2027, 2007.

Zhao, Q., Guo, W., Ling, X., Liu, Y., Wang, G., and Xie, J.: Analysis of Evapotranspiration and Water Budget for Various Land Use in Semi-Arid Areas of Tongyu, China, Clim. Environ. Res., 18, 415-426, 2013 (in Chinese).
Zhou, J., Zhang, Z., Sun, G., Fang, X., Zha, T., McNulty, S., Chen, J., Jin, Y., and Noormets, A.: Response of ecosystem carbon fluxes to drought events in a poplar plantation in Northern China, Forest Ecol. Manag., 300, 33-42, 2013.

Zhou, L., Zhou, G. S., Liu, S. H., and Sui, X. H.: Seasonal contribution and interannual variation of evapotranspiration over a reed marsh (Phragmites australis) in Northeast China from 3-year eddy covariance data, Hydrol. Process., 24, 1039-1047, 2010.

Zhu, G., Lu, L., Su, Y., Wang, X., Cui, X., Ma, J., He, J., Zhang, K., and $\mathrm{Li}, \mathrm{C}$. : Energy flux partitioning and evapotranspiration in a sub-alpine spruce forest ecosystem, Hydrol. Process., 28, 50935104, 2014. 